\title{
The US college loans system: Lessons from Australia and England
}

\author{
Nicholas Barr ${ }^{\mathrm{a}}$, Bruce Chapman ${ }^{\mathrm{b}}$, Lorraine Dearden ${ }^{\mathrm{c}, *}$, Susan Dynarski ${ }^{\mathrm{d}}$ \\ ${ }^{\mathrm{a}}$ London School of Economics and Political Science, United Kingdom \\ ${ }^{\mathrm{b}}$ Australian National University, Australia \\ ${ }^{\mathrm{c}}$ University College London, Institute for Fiscal Studies and IZA, United Kingdom \\ ${ }^{\mathrm{d}}$ University of Michigan and NBER, USA
}

\section{A R T I C L E I N F O}

\section{JEL classification:}

H28

$\mathrm{I} 22$

I28

J24

\section{Keywords:}

Income-contingent loans

Mortgage-type loans

Student loan design

Loan defaults

\begin{abstract}
A B S T R A C T
There is wide agreement that the US student loan system faces significant problems. Seven million borrowers are in default and many more are not repaying for reasons such as returning to school, or economic hardship. The stress of repayments faced by many students results at least in part from the design of US student loans. Specifically, loans are organised like a mortgage, with fixed monthly repayments over a fixed period of time, creating a high repayment burden on borrowers with low income. This paper draws on the experience of the income-contingent loan (ICL) systems operating in England and Australia, in which monthly or two-weekly repayments are related to the borrower's income in that period, thus building in automatic insurance against inability to repay during periods of low income. We discuss the design of this type of loan in detail since such an exercise seems to be largely absent in the US literature. Drawing on data from the US Current Population Survey (CPS) we provide two main empirical contributions: a stylised illustration of the revenue and distributional implications of different hypothetical ICL arrangements for the USA; and an illustration of repayment problems faced by low-earning borrowers in the US loan system, including a plausible example of adverse outcomes with respect to Stafford loans. Importantly, we compare repayment burdens under the existing and alternative systems. Our illustrations show how US mortgage-type loans can create financial difficulties for a significant minority of US borrowers, difficulties which an ICL is designed to address. We note also that the current small and ineffective income-based repayment system in the US has few of the characteristics of an ideal ICL.
\end{abstract}

\section{Background}

This paper ${ }^{1}$ examines potential reform of student loan arrangements in the US. The issues are addressed in several ways, including conceptual and empirical examination of the Australian and English approaches to the design of student loans, which in both countries is based on a universal income-contingent loan (ICL) system. Though an apparently similar approach is an option in the US, through the so-called income-based repayment (IBR) loan system, appearances can be deceptive. We seek to explain why.

Unlike other variants of US student loans, the IBR shares a major feature of ICL: monthly repayments depend on a debtor's future income. But there are significant operational and design differences that lead us to conclude that, in effect, there is not now even the basis of an ICL in the US. In comparison with the English and Australian arrangements: IBR coverage is low; eligibility is severely restricted; there are major administrative complexities; and design features effectively negate the critically important insurance aspects of an ideal ICL. These issues are raised at different points.

It is generally agreed that there is room for major improvements in the arrangements for student loans in the US. Latest data from the National Student Loan System ${ }^{2}$ shown in Table 1 show that at the end of

\footnotetext{
* Corresponding author.

E-mail address: 1dearden@ifs.org.uk (L. Dearden).

${ }^{1}$ We are grateful for helpful comments from participants at a conference Restructuring Student Loans: Lessons from Abroad, Washington DC, 13 June 2016 , a Higher Education Finance Workship, Tongji University, 20 October 2016, Richard Goeltz, and three anonymous referees. Bruce Chapman wishes to acknowledge financial assistance from the Australian Research Council (LP1 102200496) and the College of Business and Economics at the Australian National University. Bruce Chapman and Lorraine Dearden would like to gratefully acknowledge financial assistance received from the ESRC funded Centre for the Microeconomic Analysis of Public Policy at IFS, grant no. RES-544-28-5001 and funding from the HEFCE and ESRC funded, Centre for Global Higher Education at UCL - IOE, grant no. ES/ M010082/1. All errors and omissions are the responsibility of the authors.

${ }^{2}$ See http://studentaid.ed.gov/sites/default/files/fsawg/datacenter/library/PortfoliobyLoanStatus.xls. Earlier analysis of this data can be found in Dynarski (2014).
} 
Table 1

Federally managed stock of student debt, March 2018.

\begin{tabular}{|c|c|c|c|c|}
\hline \multirow[t]{2}{*}{ Loan status } & \multicolumn{2}{|c|}{ Dollars outstanding } & \multicolumn{2}{|c|}{ Recipients } \\
\hline & $\$$ in billions & $\%$ of total & Millions & $\%$ of total \\
\hline In-school & 142.5 & 11.9 & 7.2 & 17.6 \\
\hline Grace & 25.1 & 2.1 & 1.3 & 3.2 \\
\hline Repayment & 643.0 & 53.8 & 18.6 & 45.4 \\
\hline Deferment & 126.3 & 10.6 & 3.8 & 9.3 \\
\hline Forbearance & 119.3 & 10.0 & 2.8 & 6.8 \\
\hline Cumulative in default & 130.3 & 10.9 & 7.0 & 17.1 \\
\hline Other & 9.6 & 0.8 & 0.3 & 0.7 \\
\hline Total & 1196.1 & 100.0 & 41.0 & 100.0 \\
\hline
\end{tabular}

Note: Recipient counts are based on individual loans. As a result, recipients may be counted multiple times across varying loan statuses.

March 2018 seven million borrowers were in default, with the stock of outstanding debt just over \$1.3 trillion. Many more borrowers were in deferment, forbearance, non-defaulted bankruptcy or in disability status. $^{3}$ These groups together account for just over $30 \%$ of the outstanding stock of student debt.

In addition, students face extraordinary complexity, with choice from many different loans with different and frequently opaque financial implications. In contrast, the English and Australian systems are based on a single, mostly transparent, income-contingent student loan. Income-contingent (in US parlance, income-based) loans, proposed in concept by US economists Milton Friedman and James Tobin, have been adopted successfully in Australia (since 1989), New Zealand (since 1992) and England (since 1998).

Drawing heavily on English ${ }^{4}$ and Australian experience, the paper outlines an ICL approach that has the potential to resolve some of the important issues of the current US student loan system. The paper has two goals: to provide empirical comparisons of the effects of different types of loan schemes for the US; and to provide a template that sets out the choices to be made if a broadly-based ICL were to be considered as part of a reform initiative.

It is important to understand what we are intending and not intending. Specifically, our intention is to explain the core conceptual problems of the main student loan arrangements in the US. In addition, we set out an ICL strategy. The practical purpose of the latter element is unusual in a research contribution, highlighting the occasional implicit ambiguities arising from the cross-over between enquiry and policy development. For that reason, considerable effort is made to explore all the design parameters of an ICL in order to set the scene for the statistical illustrations that follow.

Our empirical exercises are original contributions with respect to the US debate about different student loan systems - the current mortgage-type Stafford loan and a hypothetical ICL which differs in fundamental ways from the current IBR loan in the US. Both sets of analysis use data from the 2014 to 2017 March income supplement of the US Current Population Survey. The illustrations of the two types of loan seek to address the following questions:

(i) What effects would a hypothetical ICL have on distributional

\footnotetext{
${ }^{3}$ These last two categories are included in the 'Other' category. Cumulative in default includes loans that are more than 360 days delinquent. Deferment includes loans for which repayments have been postponed in circumstances such as returning to school, military service, or economic hardship. Forbearance includes loans for which repayments have been temporarily suspended or reduced as a result of certain types of financial hardship.

${ }^{4}$ The system of ICLs to cover living costs (known as maintenance loans) is UKwide (i.e. England, Scotland, Wales and Northern Ireland). England, in addition, has fee loans, which operate in the same way as maintenance loans, to cover tuition charges. Throughout the paper we use the term England as shorthand for the combination of an ICL with tuition charges.
}

outcomes for debtors and on the cost of interest rate subsidies for government; and

(ii) What are the repayment burdens of Stafford loans for low-income borrowers and how do these repayment burdens compare with a hypothetical ICL?

The exercises are highly stylised and focus only on 4-year BA college graduates. They are not intended as simulations of an economy-wide reform of US student loans, but as illustrations of the sorts of issues and potential effects of different ICL designs on both subsidies and distribution.

Our findings look at the overall picture. There is wide variation in the loan experience of higher education debtors in the US and indeed some graduates have no or low debt. In addition, there are likely to be positive correlations between a person's total debt and their eventual lifetime incomes (Looney and Yannelis, 2019), which can mitigate concerns about debt levels per se. Whilst we address both of these issues, we do so in a highly stylised way. Unwrapping these myriad issues for US college loans is a substantial puzzle; our contribution is limited to shining a light on some fundamental design issues. The plan is as follows.

Section 2 explains the advantages of ICLs, which seem to receive little consideration in the US. Section 3 briefly describes the systems in Australia and England, and Section 4 draws out the implications of those arrangements. That discussion sets the scene for Section 5 which considers the key design elements in an ICL loan and the considerations that underpin the choice of parameters. Section 6 looks at the distributional implications of possible ICL systems in the US and illustrates one of these systems for borrowers at different points of the income distribution. Section 7 compares the repayment profiles of these borrowers with what occurs under Stafford Loans. For the last of these, we take highly stylised examples of how difficult financial life can be for people in low-income circumstances.

\section{Why income-contingent repayments for student loans? ${ }^{5}$}

\subsection{Income-contingent repayments are very different}

Mortgage style loans involve a nominal repayment of \$X per month for $n$ years. With a mortgage style loan:

- An increase in the interest rates raises monthly nominal repayments.

- What is fixed is the duration of the loan; the variable component is the fraction of a person's income absorbed by repayments (referred to as the repayment burden).

- Because repayments are constant (in the absence of interest rate changes), the repayment burden increases if income falls.

With an income-contingent system, in contrast, repayments are $x$ per cent of the borrower's current income until he/she has repaid the loan. Further, in virtually all ICL systems payments are taken only after income reaches a threshold (to protect those facing financial stress). In a mortgage-type loan, repayments are for a fixed duration. In an ICL system the duration of repayments is variable, being longer for borrowers with lower incomes, and unique to each debtor because the path of lifetime income is similarly unique.

Income-contingent loans, though genuine loans, are very different from mortgage-type loans. For example:

- An increase in the interest rate has no effect on monthly repayments; what changes is the duration of the loan.

- What is fixed is the fraction of a person's marginal or total income absorbed loan repayments.

\footnotetext{
${ }^{5}$ For fuller discussion, see Barr (2012, 2017).
} 
- If a person's income rises, their repayments increase but their repayment burden cannot exceed the repayment rate defined in the policy.

For the reasons set out below, an income-contingent design to finance investment in human capital is more consistent with economic principles than a conventional loan.

\subsection{Why not mortgage-type loans?}

A central finding of a study of professional incomes by Friedman and Kuznets (1945) was that the return to human capital was higher than to physical capital. Having ruled out other explanations the only hypothesis left standing was that the cause was capital market imperfections, particularly the risk to borrower and lender of an unsecured loan. ${ }^{6}$ Friedman and Kuznets set out in a footnote (p. 90) what, at the time, was a deeply radical notion - that individuals sell 'shares' in their future income as a way of financing investment in their human capital.

An implication of the Friedman and Kuznets finding is that there will be under-investment in human capital. That inefficiency matters because it implies a loss both of private benefits and the generally agreed external benefits associated with investment in higher education.

Friedman (1955) took the issue forward, arguing that conventional mortgage-type loans work well for home loans but not for investment in skills because of two strategic problems in the market for student loans:

- There is a lack of collateral: in contrast with home loans, there is nothing for a bank to sell if a student defaults; and, again unlike home loans, students can emigrate, leaving no forwarding address. In addition,

- There is asymmetric information: students are better informed than lenders about whether they aspire to careers in financial markets or the arts.

The first problem implies excessive risk for borrowers (who have no asset to sell to pay off the loan if their subsequent income is low); and both problems imply excessive risk for lenders. As a result, with conventional mortgage-type loans, investment in human capital is too low. The deterrent applies to all students, but particularly to those from poorer backgrounds who tend to be (a) less well informed and (b) less able to absorb financial risk.

These market failures imply that to achieve an efficient level of investment in human capital a loan system needs two elements:

- Consumption smoothing: the loan needs to be large enough to provide effective consumption smoothing over the course of the loan. For the reasons set out above, however, exposing the individual borrower to the risk of an unsecured loan leads to underinvestment in human capital. Thus good design also requires:

- Insurance: if consumption smoothing is to be effective (that is, people borrow enough to finance the efficient amount of investment in human capital), the loan needs in addition to provide an element of insurance against low income.

\subsection{Loans with income-contingent repayments}

Having identified the capital market imperfections outlined above, Friedman goes on to point out that:

"The device adopted to meet the corresponding problem for other

\footnotetext{
${ }^{6}$ For a more detailed study of capital market imperfections see Kodde and Ritzen (1985).
}

risky investments is equity investment plus limited liability on the part of shareholders. The counterpart for education would be to "buy" a share in an individual's earning prospects: to advance him the funds needed to finance his training on condition that he agree to pay the lender a specified fraction of his future earnings" (1955, page 138) which:

On that basis he advocates loans from government, in return for

"The individual would agree in return to pay to the government in each future year $\mathrm{x}$ per cent of his earnings in excess of $\mathrm{y}$ dollars for each $\$ 1000$ that he gets in this way. This payment could easily be combined with payment of income tax and so involve a minimum of additional administrative expense" (page 140).

Based on similar thinking, Yale University introduced a system of ICLs in the $1970 \mathrm{~s}$. The main reason why that system failed, it can be argued, is that a university lacks a sufficiently robust capacity to collect repayments, particularly of an income-contingent form. ${ }^{7}$

Thus the design addresses the lack of collateral (a) by using the tax system or equivalent to enforce repayment (reducing risk to the lender) and (b) through income-contingent repayments (reducing the risk to the borrower). The design does not address adverse selection directly. However, to the extent that the loan is on better terms than a conventional private loan, the incentive to adverse selection is less powerful.

The operation of student loans is analogous to social security and can be designed on similar principles. For example, pensions redistribute from a person's younger to her older self; student loans redistribute from middle years to earlier years. ${ }^{8}$

\subsection{Different income-contingent designs}

An income-contingent mechanism has two generic forms:

- With a graduate tax (as in Friedman), borrowers repay a fraction of their earnings for life or (say) till retirement. This is equity finance: repayments are contingent on lifetime income; thus people with higher lifetime earnings repay more in present-value terms.

- With loans, repayment continues until the borrower has repaid some specified amount, for example, $100 \%$ of the amount borrowed in present value terms. In this design, income contingency affects the time path of repayments but, except for the lifetime poor, not the total repayment.

In what follows we concentrate on loan, not equity, finance and do not consider the alternative of a graduate tax.

\subsection{Different ways of implementing income-contingent repayments}

Repayments can be organised in different ways.

- Based on current income, as in Australia, New Zealand and England. Since repayments adjust automatically to current earnings, this is the best method so long as a country has the institutional capacity to implement it effectively;

- Based on past income, as in Hungary; and

- Through a hybrid arrangement, as in the Netherlands. The Netherlands has a traditional mortgage-type system, but if a person's earnings are low, he/she can contact the student loans

\footnotetext{
${ }^{7}$ As well, it was argued perceptively at the time (Nerlove, 1975) that unusual adverse selection and moral hazard features of the Yale plan would lead to its implosion.

${ }^{8}$ For an early UK proposal in which student loan repayments are linked to social security contributions, see Barr (1989).
} 
administration and request a lower repayment rate, losing the benefits of automaticity - benefits in terms of lower compliance costs for the borrower and lower administrative costs.

\subsection{Key elements in design}

The core elements of an ICL are:

- The repayment rate(s), that is, repayments as a per cent of a person's current income;

- The repayment threshold, that is, the level of income at which repayments start;

- The interest rate and/or loan surcharge/administrative charge;

- A cap on total and/or annual borrowing from the student loan system ${ }^{9}$

- The maximum number of years of repayment, that is, forgiveness after $n$ years;

- Conditions for early repayment;

- A robust collection mechanism.

We discuss these elements in Section 5, both individually and in terms of their interactions.

\section{How the English and Australian student loan systems work: tuition $^{10}$}

Universities in England and Australia operate in the public sector with tuition charges set by government. Fee levels have changed considerably over the last 20 years and are currently:

(i) A maximum of GBP 9250 (USD 12,000) per full-time student per year in England, irrespective of subject, with over 95\% of institutions charging this amount; and

(ii) Between about AUD 6000 (USD 4,500) and AUD 9000 (USD 6500) per full-time student per year in Australia depending on the course studied, with three tiers (for example, law and medicine are in the top tier and arts and humanities are in the bottom).

Upon enrolment, domestic students choose between paying tuition up-front or deferring their obligation through an ICL system. The vast majority (88\% in Australia, ${ }^{11} 94 \%$ in England ${ }^{12}$ ) choose to defer, and a student's debt is recorded and linked to his/her unique social security/tax file number. When a borrower starts work, employers withhold loan repayments based on the borrower's current income in the same way as they withhold income tax and, in some countries, social security contributions. Outstanding debt is recorded and reconciled within a government agency, which can be the tax authorities or a separate loans administration, such as the UK Student Loans Company.

\footnotetext{
${ }^{9}$ An alternative design, tried on a small scale for specific types of student, is an ICL design with different parameters (e.g. interest rate, repayment rate, repayment duration) for different borrowers, depending on the lender's view of the riskiness of the borrower (see Palacios, 2014).

${ }^{10}$ As noted, we use the term England as shorthand for the combination of an ICL with tuition charges. This section considers only loans to cover tuition fees though the UK system (unlike Australia) also has maintenance loans. The administrative arrangements are identical although policy concerns relating to interest rate subsidies are more important in a system that covers living costs because the resulting debt is larger, hence the distortion caused by an interest rate subsidy is greater.

${ }^{11}$ Data from Australian Department of Education Student Statistics, 2016/17.

${ }^{12}$ In 2015/16 in England, 93.8\% of students took out fee loans and 89.5\% of students took out maintenance loans. See Tables 4A and 4B in https://www.slc. co.uk/official-statistics/full-catalogue-of-official-statistics/student-support-forhigher-education-in-england.aspx.
}

In both Australia and England, a borrower has no repayment obligation unless his/her income exceeds a certain amount, GBP 25,000 per year ${ }^{13}$ (USD 32,000) in England and AUD 57,000 (USD 42,000) per year in Australia. Above these thresholds loan repayments are an increasing proportion of income, but cannot exceed 9 and $8 \%$ of incomes, respectively in England and Australia. When the loan has been fully repaid, the employer is informed and collection of repayments ceases; the median duration is about 9 years in Australia ${ }^{14}$ and 30 years in England (where average debts are much larger), although the variance is considerable; in Britain all outstanding loans are forgiven after 30 years; ${ }^{15}$ Australia has no maximum repayment duration. Both systems charge interest, and both include an element of interest subsidy, ${ }^{16}$ an issue considered in more depth below.

\section{Key conceptual features of the English and Australian loan systems}

Several critical features of the English and Australian arrangements contrast with those in the US.

\subsection{Repayment burdens}

A critical concept is that of the "repayment burden" (RB), the proportion of a borrower's income required for loan payments. The most important benefit of the Australian and English ICL systems is that by design there is a maximum $\mathrm{RB}$ of 8 and $9 \%$, respectively. This feature contrasts sharply with the typical situation in the US, where RBs for an individual borrower can fluctuate widely, and also differ considerably between student debtors, as noted in Dynarski (2016).

RBs are a crucial aspect of student loan design because they reflect the difficulty or ease of meeting repayment obligations. With non-ICL systems, for example standard Stafford loans in the US, a borrower is required to repay a fixed amount each month for 10 years, irrespective of their financial capacity to do so. Thus borrowers experiencing unemployment or low earnings through non-graduation (a particularly likely outcome for borrowers who did not complete their degree from the for-profit sector), face high RBs, causing hardship and in many cases leading to default. By design, this cannot happen with an ICL system the main benefit of such an arrangement.

Chapman and Dearden (2017) present calculations of RBs for BA graduates in the US at different percentiles in the US earnings distribution but only for those in the labour force. The results reported in Sections 6 and 7 extend that analysis to take into account the effect on income both of unemployment and not being in the labour force, each of which has an obvious bearing on RBs. Though most graduates do not experience difficulties, those in the 10th and 20th centiles face serious problems, particularly early in their careers when incomes are typically low. With hypothetical illustrations, Chapman and Dearden report RBs of over $100 \%$ for young men and women in the 10th centile of BA earnings at the age of 22; and even those in the 20th centile face high RBs of over $30 \%$ for men and $40 \%$ for women early in their career.

High repayment burdens have multiple ill effects. They lead to damaged credit reputations; and, in ways that are neither efficient nor equitable, they can adversely affect labor market decisions (whether to work in the public or private sector, take more time to find an appropriate job, do volunteering, or look after family members) and decisions

\footnotetext{
${ }^{13}$ Before April 2018 this threshold was GBP 21,000 per year.

${ }^{14}$ Published data from the Australian Department of Education higher education website, Student Statistics, 2016/17.

${ }^{15}$ Estimates (Belfield et al., 2017) suggest that 83\% of borrowers in England will not repay in full, and therefore repay for 30 years, which means the median is also 30 years.

${ }^{16}$ The interest subsidy element in England was reduced in 2012 (for analysis, see Barr, 2012).
} 
about family formation (partnership and when to have children). Chapman and Dearden (2017) illustrate these potential problems with the example of a young female teacher who has a child.

A central advantage of the ICL arrangements in England and Australia is that such ill-effects are ruled out by design.

\subsection{Administrative simplicity}

As Dynarski (2016) stresses, though US borrowers can choose an IBR method from the plethora of loan options available, the system is complicated to navigate and administratively burdensome. For example, being part of the US IBR must be negotiated on an annual basis and requires a fairly sophisticated understanding of the present value of expected repayments under different options. In the English and Australian systems, in contrast, repayments adjust automatically; borrowers are not required to navigate through the myriad rules, nor to make complex decisions about their loan choices and repayment paths. For employers, it is a simple matter of an additional element of withholding on behalf of the government, alongside income tax, medical insurance and/or social security.

Stiglitz (2014) has labelled these advantages "transactional efficiencies" and promotes this aspect of the English and Australian policies as one of the most important positive features of ICL. The resulting benefits take two forms:

- The marginal cost of collection is small because the system builds on an existing administrative income-contingent collection apparatus. ${ }^{17}$

- As noted, the benefit for the borrower is that repayments adjust automatically to his/her financial circumstances.

\subsection{Accuracy in adjusting the level of monthly repayments to current financial circumstances}

ICL repayments in England or Australia accurately reflect a borrower's current capacity to repay, since repayments are collected on the basis of the borrower's current weekly, fortnightly or monthly income. ${ }^{18}$ This aspect is important for the insurance element built into ICLs. This is not the case in the US IBR option since repayments are based on the previous year's income rather than current income (Dynarski, 2016). ${ }^{19}$

The distinction between past and current income would be immaterial with stable and predictable incomes, but that is not the way the world works for borrowers. The incomes of young people are least stable, and depend significantly on the state of the labour market when first seeking full-time employment. Thus the US IBR is not income-contingent for the most important subset of borrowers those with unstable employment and income and/or hours of work. Unemployment benefits and tax credits are rightly based on current circumstance; for the same reasons, the insurance element in ICLs requires repayments based on current earnings not past earnings.

\footnotetext{
${ }^{17}$ Administrative costs in the Australian and UK systems are about 3 or 4 per cent of the annual revenue collected (Chapman, 2014).

${ }^{18}$ ICLs typically involve employer withholding from wages/salaries, that is earnings, although there are later financial year adjustments to include unearned income as well. In the rest of the paper we use the terms "income" and "earnings" interchangably.

${ }^{19}$ There is an additional design flaw with the US IBR, which is that debts that remain unpaid after 25 years are treated as income and taxed accordingly. This curiosity essentially removes an important aspect of the insurance benefits that motivate and justify ICLs in other countries.
}

\subsection{Accuracy in adjusting the repayment duration to individual circumstances}

An implication of the English and Australian ICLs is that the repayment period for higher-earning income borrowers will generally be shorter and for low-earning graduates longer.

There is no obvious argument for having a fixed 10-year (or indeed 20- or 30-year) term for student loans. Indeed, the typical US term of 10 years is short compared with student loans in other countries; for example, in the Thai and Canadian mortgage-type student loan systems the repayment periods are 15 and 18 years respectively. It can be argued that it is efficient if the lifetime of a loan is related to the lifetime of the asset, hence 3-year car loans and 25year home loans. Since human capital has value throughout a person's working life, the option of a long repayment duration is efficient, and as well it reduces the risk of default. Note that, as discussed below, a well-designed ICL allows early repayment if that is what the borrower wishes.

\subsection{Minimising taxpayer subsidies with ICL}

The extent of taxpayer subsidy associated with an ICL depends on its design, discussed in Section 5.

It is possible to design an ICL system that is broadly cost neutral. Key variables include a combination of smaller loans, real interest rates above the government cost of borrowing, loan surcharges, lower repayment thresholds, higher repayment rates, longer loan terms, and a healthy labour market with good earnings growth. Some of these variables can be controlled, others can not. A good ICL system should be transparent, easy to understand, easy to access, easy to administer, placing a manageable burden on borrowers once they enter the labour market, and basing repayments on current earnings.

The English and Australian experience points to the following conclusions for policy design:

- ICLs deliver major benefits in terms of consumption smoothing and insurance because they eliminate concerns about high repayment burdens and hence largely eliminate defaults;

- Repayments through employer withholding based on current income is the simplest and cheapest approach for both lenders and borrowers;

- A system without the complications of reapplication has significant administrative and conceptual benefits both for government and borrowers; and

- The parameters of an ICL are critical design issues, to which we now turn.

\section{Designing an ICL system}

This section discusses in turn the elements in an ICL noted earlier: the repayment function (that is, the repayment rate(s) and repayment threshold); the interest rate on the loan and/or the loan surcharge; the cap on borrowing from the system; forgiveness after $n$ years; conditions for early repayment; and a robust collection mechanism.

Student loans have multiple objectives, including consumption smoothing and equitable access (hence avoiding high repayment burdens), and fiscal parsimony (thus allowing loans to be large enough to provide good consumption smoothing, and sufficiently widely available to bring about efficient levels of investment in skills). The choice of parameter values will depend on:

- The relative weights given to these different objectives;

- The choice of the other parameters, i.e. the parameters interact with each other;

- The size of the loan; 
- The level, distribution and projected rate of change of graduate earnings;

- The tax and benefit regime operating in a country, and the tax base;

- Political sensitivity connected with real interest rates and surcharges.

\subsection{The choice of repayment rate}

- In England, the 9\% repayment rate applies only to earnings above the threshold of GBP 25,000 per year; ${ }^{20}$ thus the repayment for someone earning GBP 26,000 per year is GBP 90, that is $9 \%$ of GBP 1000. In Australia, the first income threshold is AUD 57,000 per annum, and at that income debtors are required to repay $4 \%$ of their total income, or about AUD 2200. This suggests a "cliff-edge" as income crosses the threshold, and it is likely that this has behavioural effects, such as tax bunching. ${ }^{21}$

- A higher repayment rate brings in more repayments faster, but creates a larger potential distortion to labour supply. In England, the repayment rate of $9 \%$ means that the increase in the marginal tax rate above the threshold is $9 \%$ for all graduates (until the loan is repaid). In the Australian system the high short-term costs incurred at the first threshold have now been reduced as a result of legislation passed in December 2017. From 2018-19 the first threshold has been reduced to AUD 52,000 per annum with a $2 \%$ repayment rate increasing incrementally to a maximum of $8 \%$ for those earning AUD 107,200 or above. ${ }^{22}$

\subsection{The choice of repayment threshold}

- Other things equal, a lower repayment threshold increases repayments, making it possible, for example, to have a lower repayment rate at any given level of income.

- The case for a higher threshold is to avoid the high effective marginal tax rates faced by many low-earning recipients of incometested benefits, and to reduce financial stress on low earners. A higher threshold disentangles student loan repayments from the welfare system, with both efficiency and equity gains, but reduces revenue at the same repayment rates.

- The choice of threshold depends on the balance between repayment flows and social concerns, and will depend crucially on the median level of income in a country, the extent of income inequality, its tax and benefit systems, and the efficiency of the tax collection/employer withholding system.

\subsection{The choice of interest rate}

- If a policy aim is to keep taxpayer subsidies small, one approach is an interest rate on the loan which is not below the government's cost of borrowing. An interest rate below the cost of finance means that no borrower repays in full in present value terms, an outcome which can be expensive in fiscal terms (especially if the government cost of borrowing is high). However, a lower interest rate may be politically more palatable, and may reduce adverse selection, and is also more progressive in terms of the proportion of the loan paid by the cohort

\footnotetext{
${ }^{20}$ As noted, before April 2018, GBP 21,000 per year.

${ }^{21}$ An advantage of using a total instead of a marginal income basis of collection is that the repayment flow will be stronger. Chapman and Leigh (2009) find evidence of bunching in the Australian system, but it seems to be empirically very small (although that was when the first repayment rate was only $3 \%$ of income and it has since increased to $4 \%$ ). The new lower threshold and initial rate operating from 2018-19 will reduce this problem.

${ }^{22}$ See https://www.ato.gov.au/Rates/HELP,-TSL-and-SFSS-repaymentthresholds-and-rates/\#HELPandTSLrepaymentthresholdsandrates201
}

of borrowers in present value terms across the earnings distribution. We return to the issue in Section 6.

- If the interest rate is set above the government's cost of borrowing, borrowers who repay their loan in full repay more than the cost of their loan in present value terms. However this is no longer necessarily progressive within the cohort of borrowers (since the richest graduates repay their loan faster and hence contribute less proportionately in present value terms from the higher interest rate).

\subsection{The choice of surcharge}

- A loan surcharge is an alternative to a positive real interest rate, or an option alongside it. ${ }^{23} \mathrm{~A}$ surcharge works by adding $x$ per cent to the amount borrowed; for example a $10 \%$ surcharge on a loan of $\$ 10,000$ requires the borrower to repay $\$ 11,000$. Unlike with respect to compounding real interest rates, a surcharge is transparent and can help to maintain progressivity within the cohort of borrowers. This is because a surcharge with no real interest rate on the debt afterwards means that the highest income earners repay most quickly and thus have lower interest rate subsidies from indexation of the debt only to price change.

- A possible disadvantage is that a surcharge, particularly if large, may affect the decision to take out a loan, that is, create adverse selection. There is no evidence for this response with the surcharge in the Australian ICL, in part because the system is mandatory. ${ }^{24}$

\subsection{Maximum number of years of repayment}

- In a system with a positive real interest rate, a lower maximum repayment duration is more progressive (since lower earners are increasingly protected), but at the expense of less revenue.

- England has a maximum repayment duration of 30 years, that is, any outstanding loan balance after 30 years is forgiven. In Australia, by contrast, there is no maximum period of repayment but implicitly it is set to be the death of a debtor.

\subsection{Conditions for early repayment}

In a well-designed system borrowers should be able to repay early, in part or fully, with no penalty, so that nobody is forced to take longer to repay than they wish. A well designed system should have no incentives for or against repaying early and should ensure that there is no loss of revenue from early repayment.

\subsection{A robust collection mechanism}

As discussed earlier, employer withholding on the basis of current earnings is (a) cheap, (b) robust in a country like the US, and (c) essential if the insurance element in the loan is to be effective. Retrospective collection of ICL repayments, albeit necessary for selfemployed workers, is not transactionally efficient for employees and defeats the essence of the insurance element of an ICL. As suggested by Dynarski (2016), a system in which employer withholding is done in the same way as for social security contributions, would be ideal.

In sum, an efficient and equitable loan scheme has the characteristics summarised in Box 1.

\footnotetext{
${ }^{23}$ The US Stafford Loan system currently has a loan surcharge of $1.67 \%$.

${ }^{24}$ In a sense the Australian loan system can be avoided by students paying tuition charges up-front, but being involved in the arrangement is compulsory. As noted, around $88 \%$ of students in a given year choose the loan option.
} 
Box 1

Characteristics of a good loan design

Income-contingent repayments based on current earnings. A write-off after $n$ years, or at retirement or death.

Repayment threshold, repayment rate and interest rate chosen so that:

- A graduate with 'good' earnings repays (in present-value terms) $100 \%$, or for high earners perhaps more than $100 \%$, in the latter case with a cap on maximum overpayment (in present-value terms) by any individual.

- As far as possible seeks to avoid distortions, e.g. large cliff edges or wedges.

Such a loan is designed to make a loss on people with low lifetime earnings but should seek to keep the loss on other borrowers low.

Fiscal parsimony of loan design matters, not out of a sense of the purity of the loan, but because loans that make avoidable losses reduce their capacity to fulfil their core purpose of facilitating investment in human capital. Expensive loans restrict one or more of:

- The number of loans that are made available;

- The size of loans;

- Student numbers;

- The breadth of the loan system, e.g. not covering living costs, or excluding part-time students, postgraduate students and/ or students in sub-degree tertiary education.

- Spending on more powerful pro-access policies, for example improving nursery and primary education.

Financing non-repayment The design question is where the loss on low-earning borrowers should fall: (a) on the taxpayer, or on the cohort of borrowers through (b) a cohort risk premium or (c) a surcharge.

- With a small loan any of these methods is likely to be effective.

- The larger the loan the greater the marginal loss (the marginal loss on a $\$ 1$ loan is close to zero (since almost everyone has sufficient income to repay a $\$ 1$ loan), on a $\$ 1 \mathrm{~m}$ loan the loss is close to $100 \%$ ). If loans are large, excessive reliance on any one method is generally suboptimal.

- Taxpayer subsidy: a large fiscal cost (as in the English loan), as just discussed, creates downward pressure on the number and/or size of loans, and crowds out other beneficial activities;

- Risk premium: a large loss requires a substantial risk premium, that is, an interest rate significantly above the government's cost of borrowing, risking adverse selection and creating potential political problems;

- Surcharge: a large loss requires a substantial surcharge, again raising the prospect of adverse selection.

This line of argument suggests that the loss should be covered by a mix of the three mechanisms, the mix depending on the size of the loan and country specifics.

\section{Empirical illustrations of an ICL for the USA}

This section discusses how the sort of system outlined in Box 1 might work in the US, and how the moving parts interact. In order to make such an assessment, we require good simulations of the earnings of future graduates throughout their (simulated) lifetimes. This is the only way to work out the full cost implications of different ICL designs and the full distributional implications for borrowers. In England, the Department for Education provides simulated earnings profiles for male and female graduates, which allow anyone to calculate the implications of different ICL systems for different types of graduates and the effects on government finances under different assumptions. ${ }^{25}$ The model is similar to models developed at the Institute for Fiscal Studies since 2002. ${ }^{26}$ In the US, it would be easy for the government to replicate these simulated earnings since they have the best sources of longitudinal data (for example, see Looney and Yannelis, 2015).

In the absence of such a model, the analysis presented here has the more limited aim of illustrating the workings of an ICL, using data from the 2014 to 2017 US Current Population Survey. We focus on Bachelor of Arts (BA) graduates and assume real earnings growth of $1 \%$ per year for all these graduates. We include all graduates including those not in the labour force (as noted, in contradistinction to the approach in Chapman and Dearden, 2017).

Our starting position is to assume that all BA graduates stay in the same earnings percentile throughout their life. As Dearden (2019) shows, this in no way reflects a typical earnings path for BA graduates, and will exaggerate differences in earnings across the BA graduate distribution, and will over-estimate taxpayer subsidies involved in different types of ICL systems. ${ }^{27}$ Dearden (2019) also uses the panel element in the 2014-2017 CPS data and allows for income dynamics. This allows for complex interdependence but necessarily involves the assumption that an individual's rank in the earnings distribution next period depends only on their current rank (is first order Markov). We use these dynamic simulations for most of the analysis in the paper, and we begin by looking at the implications of an example ICL scheme across the distribution of all BA graduates, initially assuming no income dynamics and then when dynamics are allowed.

We start with (a) a system with a zero real interest rate, and consider its distributional impact within the cohort of borrowers and the overall taxpayer subsidy. We then show the distributional implications of reducing taxpayer subsidies via (b) a real interest rate only or (c) a surcharge only, and (d) a real interest rate in combination with a loan surcharge.

We then illustrate the essential differences of our ICL system with a Stafford-style mortgage loan using three examples of graduates: a female BA graduate who is assumed to earn around the 35th centile of earnings at each age throughout her life, a female BA graduate who is assumed to earn around median earnings at each age throughout her life, and a male graduate who is assumed to earn around the 90th centile of the male earnings at each age throughout his life. These very different experiences have been chosen to illustrate the range of likely earnings and ICL experiences.

\footnotetext{
${ }^{25}$ See http://www.gov.uk/government/publications/simplified-studentloan-repayment-model.

${ }^{26}$ See Chowdry et al. (2012).

${ }^{27}$ We use dynamic simulations from Dearden (2019) to show the likely magnitude of these over-estimates. Studies that have analysed the PSID and/or SIPP data in the US show that individuals experience transitory and permanent employment and earnings shocks throughout their lives, for example, see Low, Meghir and Pistaferri (2010). Moreover, the big differences between the two systems is for people with even poorer labour market outcomes. The aim of the example graduates in this section is to show that that a well designed ICL can make a significant difference, even for a moderately successful graduate. We also show, that for a successful graduate, revenue streams can accrue faster than with a mortgage-type loan.
} 


\subsection{Case 1: an example ICL with zero real interest rate}

How might an ICL system work in the US, and what would be the distributional and taxpayer subsidies involved? As an illustration, we start with the following possible ICL parameters for a US system:

(i) A first income repayment threshold of $\$ 25,000$ per year and a second threshold of $\$ 40,000$ (in a policy reality these would both be uprated annually with inflation);

(ii) A marginal 3\% repayment rate on income above the first threshold increasing to $10 \%$ for earnings above the second threshold;

(iii) A zero real interest rate (that is, debt increases with inflation only);

(iv) A loan write-off after 25 years compared to no write-off. ${ }^{28}$

Our example is for an average debt of $\$ 35,000$ which is assumed to be $\log$ normally distributed with standard deviation of $\$ 20,000$. We also assume that the loan amount taken out is positively correlated with the first 10 years of graduate earnings, with a correlation coefficient of 0.3. Dearden (2019) shows the sensitivity of estimated costs to varying this assumed correlation, with lower correlations unambiguously implying larger taxpayer subsidies. A more sophisticated ICL may involve altering the parameters of the ICL according to debt level as suggested by Palacios (2014) but this is beyond the scope of this paper.

In order to compare the full distributional implications of this ICL we begin by using the simulated earnings from Dearden (2019) where firstly no earnings dynamics are assumed and then when earning dynamics are simulated from the CPS panel using copula techniques (see Dearden, 2019). ${ }^{29}$ To calculate the taxpayer subsidy we pool the male and female results using current BA conferment proportions taken from the Digest of Education Statistics for $2015 .{ }^{30}$ We assume real earnings growth of $1 \%$ per annum; and that the government cost of borrowing is the 10 -year bond rate plus 0.6 of a point which equates to $1 \%$ real or $3 \%$ nominal with our inflation assumption of $2 \%$ per annum. ${ }^{31}$

A zero real interest rate in an ICL system is always progressive within the cohort of debtors ${ }^{32}$ for all borrowers but it helps the lowest graduate earners the most. This is because those with lower incomes repay their loans for longer (and are more likely not to repay in full), and the longer a loan with a subsidized interest rate is not fully repaid, the bigger is the subsidy.

Fig. 1 shows the distributional impact (by deciles of the male and female college lifetime earnings distribution) of a zero interest rate for our baseline scenario for men and women assuming no income dynamics. We show the differences when there is debt write-off (after 25 years) and no debt write-off.

Overall, this baseline scheme involves a 38\% taxpayer subsidy with a write-off, and a $35 \%$ subsidy with no write-off. All graduates receive a taxpayer subsidy because there is a zero (that is, subsidised) real interest rate. On average women repay between $53 \%$ and $56 \%$ in presentvalue terms, and men between $74 \%$ and $76 \%$. Having a write-off makes the scheme more progressive for the cohort of borrowers but only

\footnotetext{
${ }^{28}$ With the no write-off scenario we assume all individuals retire at 65 which means that we will over-estimate the costs of such a scheme, since a significant proportion of graduates will earn beyond 65.

${ }^{29}$ In all our analysis we use the CPS variable 'pearnval' which is all earnings from wage and salary jobs, and business and farm self-employment earnings. All data was obtained from Center for Economic and Policy Research (2017).

${ }^{30}$ BA degrees conferred in 2015 were 812,669 men and 1,082,253 women (see https://nces.ed.gov/programs/digest/d16/tables/dt16_301.10.asp).

${ }^{31}$ The Stafford interest rate of $4.45 \%$ per annum nominal is the nominal government cost of borrowing based on the 10 year bond rate, currently $2.4 \%$, plus $2.05 \%$ and hence 2.45 percentage points higher than a zero real interest rate (assumed in our ICL example) with two per cent inflation. We assume a real government cost of borrowing of $1 \%$.

${ }^{32}$ Unless loans are infinitely large, in which case nobody is affected by the interest rate.
}

impacts on the bottom four deciles for women and bottom two deciles for men.

The analysis thus far has assumed that all graduates stay in the same part of the earnings distribution from the age of 23. If, instead, we use the preferred dynamic simulations of Dearden (2019), which allows for realistic earning dynamics using CPS panel data, we get a very different picture, shown in Fig. 2.

In this case the baseline scheme involves a significantly smaller taxpayer subsidy of between $13 \%$ with no write-off and $17 \%$ with a write-off. The loan write-off has virtually no impact on men, the subsidy being around $11 \%$ for both schemes. It impacts on women at all deciles, though to a much lesser extent at deciles 9 and 10. With a write-off, the subsidy for women is $19 \%$ and with no write off $14 \%$. Again, caution is needed because these dynamic simulations are based on the short panel available in a subset of the 2014 to 2017 CPS data (see Dearden, 2019).

It is important to be clear about the assumptions underlying these results. Predicting future earning dynamics is a difficult task, and with both the static and dynamic simulations we have assumed real income growth of $1 \%$ across all deciles of the income distribution. We assume that the unemployment rate and variance in earnings at every age is the same as it was in pooled CPS data from 2014 to 2017. Clearly our estimates of likely taxpayer subsidies are sensitive to these assumptions, and assuming a graduate unemployment rate that was observed after the financial crisis would alter these estimates. The results also depend on the correlation of debt to earnings, noted earlier. The taxpayer subsidy would be slightly larger if the correlation was less than the 0.3 assumed in our simulations, and particularly if debt and income were negatively correlated. With large student loans (such as those in the UK) the taxpayer subsidies involved in an ICL can be relatively large regardless of assumptions about income dynamics (see Britton, van der Erve and Higgins, 2019). Finally we are estimating the costs of the ICL based on individual gross earnings from labour income. The actual income base used for an ICL clearly impacts on estimated taxpayer costs.

We now consider two ways of reducing taxpayer subsidies and highlight the associated distributional consequences with respect to all taxpayers: increasing the real interest rate (but not while at college and when earning below the first threshold ${ }^{33}$ ); and introducing a loan surcharge.

\subsection{Case 2: raising the real interest rate}

Fig. 3 shows the relationship between the real interest rate and the extent of taxpayer subsidies for the ICL described above, for the case where we assume earnings dynamics. The figure shows that the taxpayer subsidy falls as the real interest rate increases. From the graph we can see the level of real interest necessary to make this baseline ICL system cost neutral. For the loan with no write-off it would be $2.0 \%$ real or $4.0 \%$ nominal, and with a 25 year write-off $2.9 \%$ real or $4.9 \%$ nominal. ${ }^{34}$ In what follows this is what we define as involving no overall taxpayer subsidy ${ }^{35}$ and this is identified where the lines cross the $x$ axis. It is also easy to see what interest rate would require an average taxpayer subsidy of $10 \%$ (or indeed any other taxpayer subsidy): for this example the real interest rate could be $0.4 \%$ real or $2.4 \%$ nominal if there is no write-off, or $1.2 \%$ real or $3.2 \%$ nominal with write-off after 25 years.

What are the distributional implications of increasing the real

\footnotetext{
${ }^{33}$ Later in the paper we also have scenarios where the real interest rate comes into effect upon graduation.

${ }^{34}$ The current Stafford Loan rate of $4.45 \%$ nominal is between these two cost neutral interest rates.

${ }^{35}$ Of course, this takes no account of administrative and other costs of implementing an ICL system and ignores non-completers and two year college students. Hence no taxpayer subsidy for the BA group will necessarily involve a taxpayer subsidy for the student loan system as a whole. It also ignores direct government funding for teaching and grants.
} 


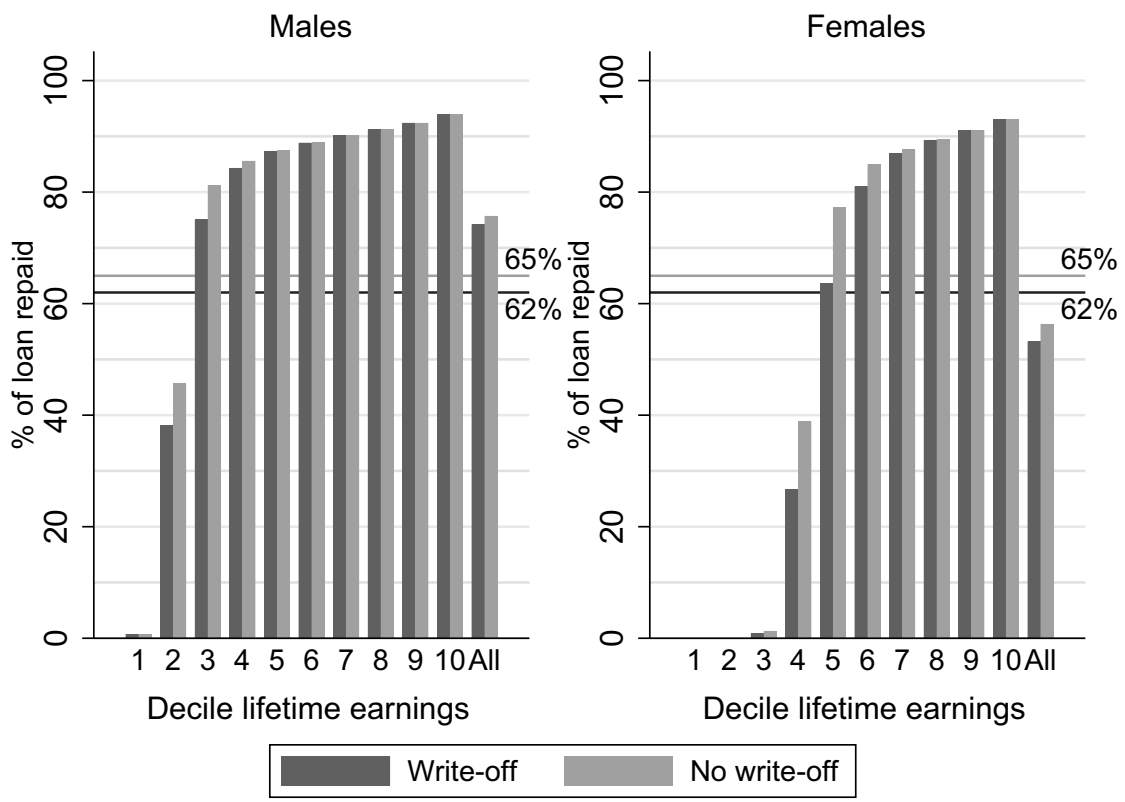

Fig. 1. Proportion of ICL Loan Repaid by Decile of Lifetime Earnings: zero real interest rate and no income dynamics.

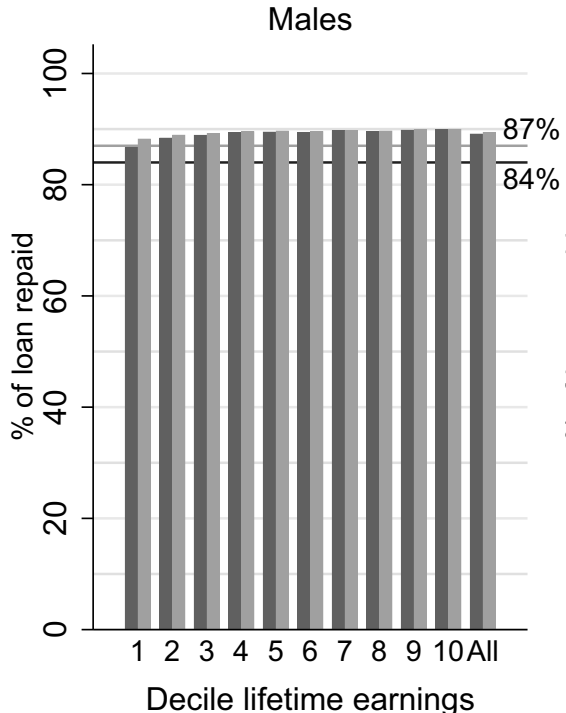

Decile lifetime earnings

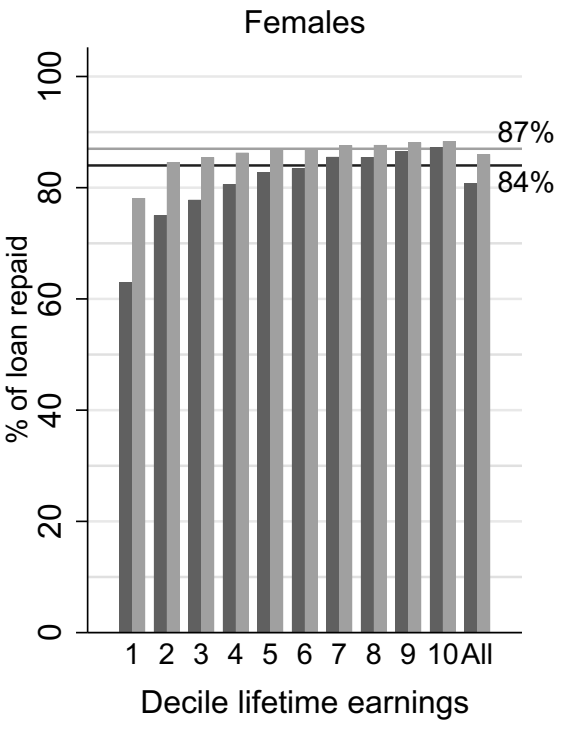

No write-off

Fig. 2. Proportion of ICL Loan Repaid by Decile of Lifetime Earnings: zero real interest rate and income dynamics.

interest rate compared to those shown in Fig. 1? To illustrate, we consider the distributional implications of a $10 \%$ taxpayer subsidy and $0 \%$ taxpayer subsidy by increasing the interest rate under both write-off scenarios. This is shown in Fig. 4.

It is clear from the figure that men repay relatively more than women in a scheme where there is a write-off. With write-off and zero subsidy, only females in the bottom two deciles repay a lower proportion of their loan in net present value terms. These differences are small because US graduate earnings mobility is very high compared to most countries.

In order to reduce the taxpayer burden, certain groups of graduates repay more than $100 \%$ of their loan in net present value terms to offset students who do not repay in full. This illustrates the insurance nature of ICLs. Having a write-off means that low-earning graduates are more subsidized, at a cost to high-earning graduates. This is a key policy choice.

\subsection{Case 3: imposing a loan surcharge}

We now look at the implications of imposing a loan surcharge. A loan surcharge simply increases the amount borrowed by a fixed proportion. If a student borrows $\$ 5000$, their outstanding debt would be $\$ 5500$ with a $10 \%$ loan surcharge. All other parameters of the ICL scheme remain the same.

In what follows we again pool male and female BA graduates using latest enrolment figures, and use our earnings data to see what surcharge would be necessary to reduce taxpayer subsidies for the baseline scenario with a zero real interest rate. This is shown in Fig. 5, which 


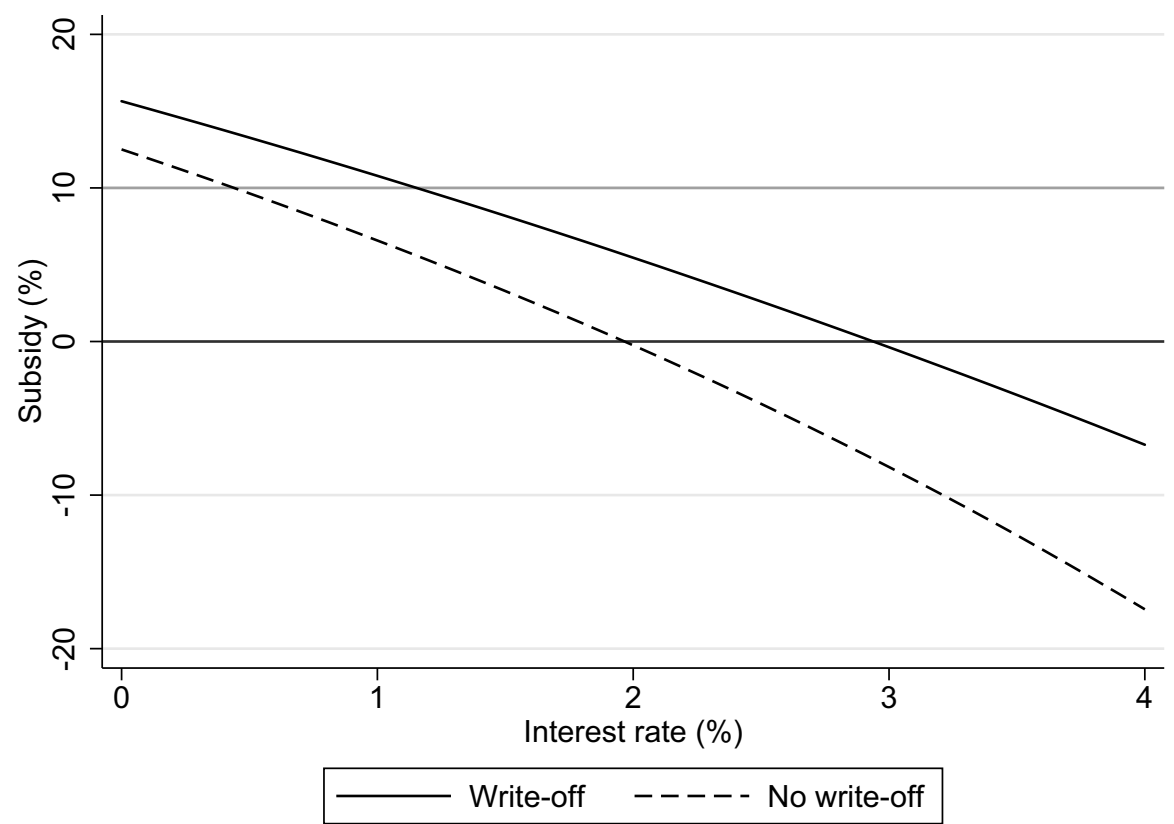

Fig. 3. Real Interest Rates and Taxpayer Subsidies. Note: The real interest rate is assumed to be zero during college and below the first threshold.
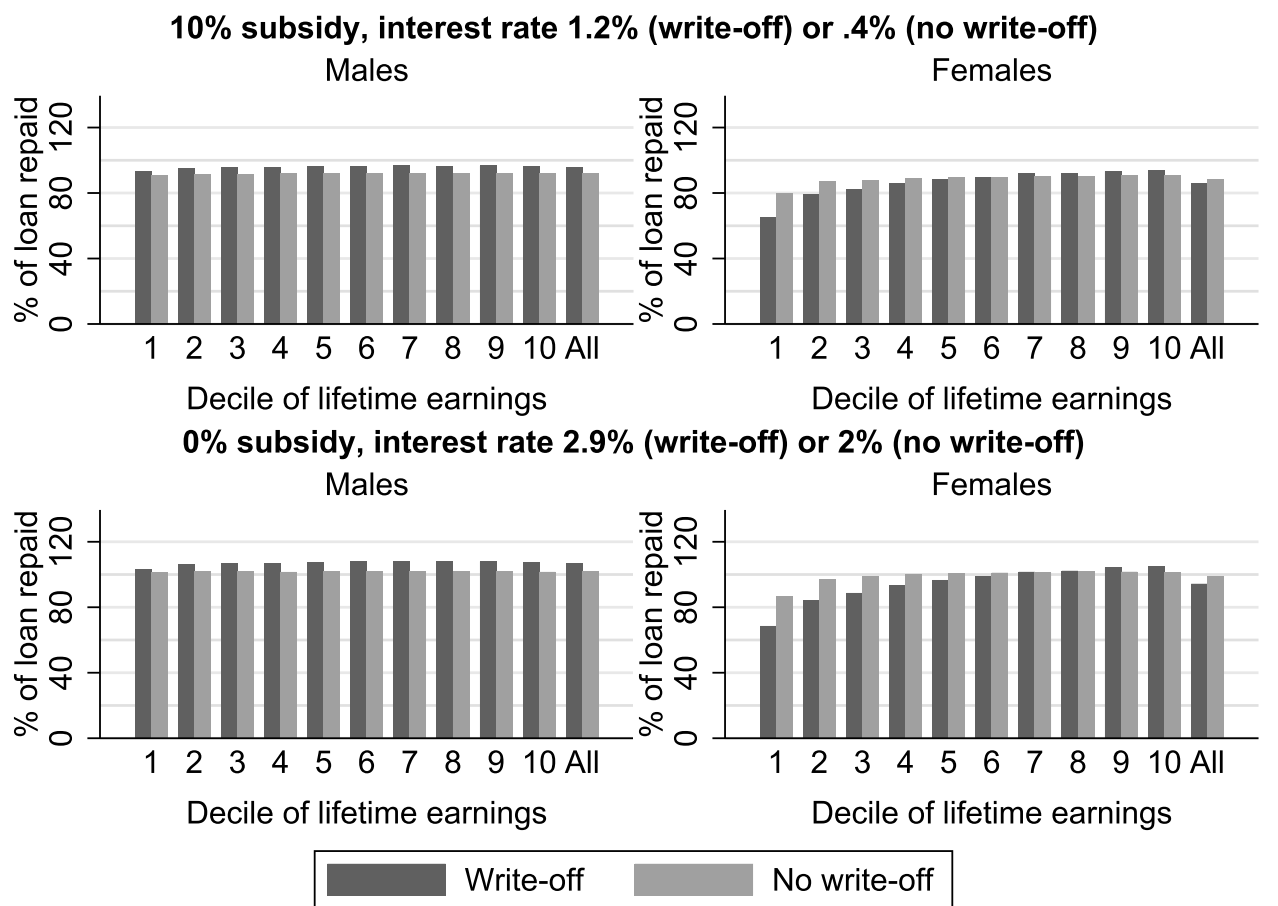

Fig. 4. Distributional Consequences of Imposing a Real Interest Rate.

illustrates how the taxpayer subsidy falls as the surcharge increases. The figure also shows the surcharge necessary to make the baseline ICL loan cost neutral, or indeed any other degree of taxpayer subsidy.

Fig. 5 shows that a surcharge of around $15 \%$ would avoid any taxpayer subsidy with no write-off, and $22 \%$ with a write-off. Alternatively, a surcharge of $3 \%$ with no write-off and $8 \%$ with a write-off would require a $10 \%$ taxpayer subsidy.

Fig. 6 shows the distributional implications of these two surcharges and shows that they are both progressive within the cohort of borrowers, i.e. as we move up the deciles of the income distribution graduates repay proportionately more. For each level of taxpayer subsidy they are more progressive than the fiscally equivalent interest rate scenario illustrated in Fig. 3. With a surcharge, the richest (mostly male) graduates repay over $100 \%$ of their loan in present-value terms with no taxpayer subsidy, and just under $100 \%$ with a $10 \%$ taxpayer subsidy. For an equivalent Stafford Loan the equivalent figure is $111 \%$ but this applies to all graduates regardless of earnings and ignoring default and delinquency.

Finally, in Fig. 7, we show the implications of a hybrid scheme which charges a real interest rate equal to the Stafford Loan rate of 2.45 real or $4.45 \%$ nominal (applied only above the first threshold and not whilst the student is at college), combined with a surcharge to make up 


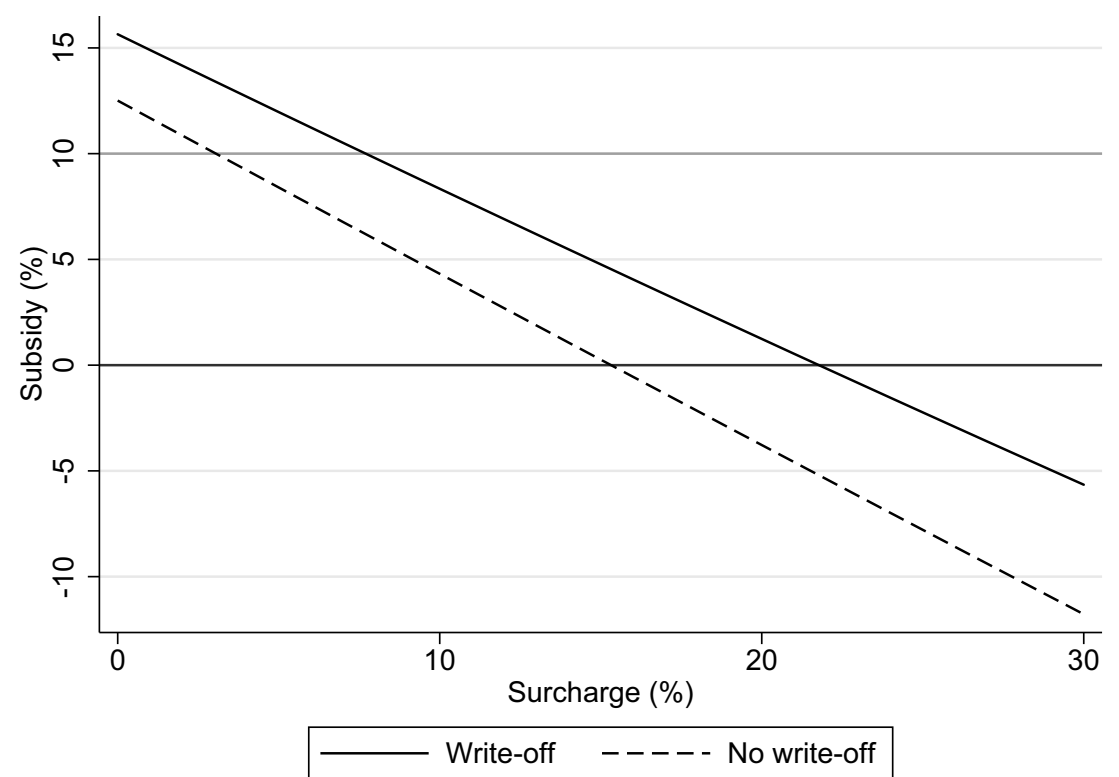

Fig. 5. Loan Surcharge and Taxpayer Subsidies: zero real interest rate.

$10 \%$ subsidy, surcharge $8 \%$ (write-off) or $3 \%$ (no write-off)

Males

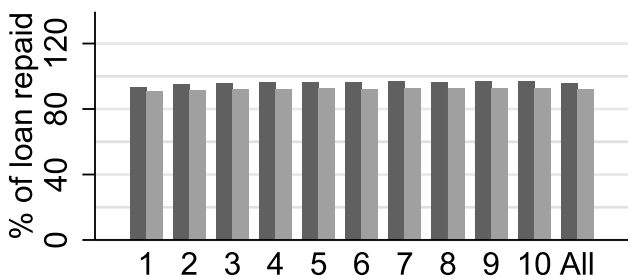

Decile of lifetime earnings

$0 \%$ subsidy, surcharge $22 \%$ (write-off) or $15 \%$ (no write-off)

Males

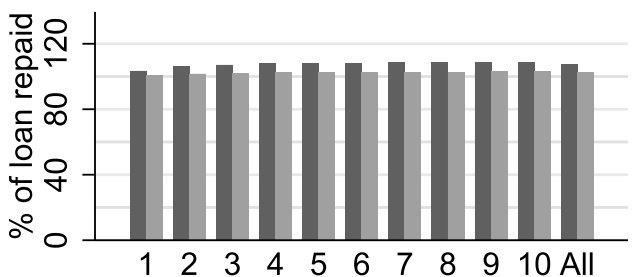

Decile of lifetime earnings
Females

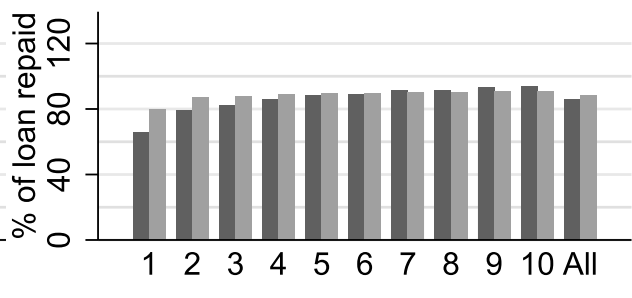

Decile of lifetime earnings

Females

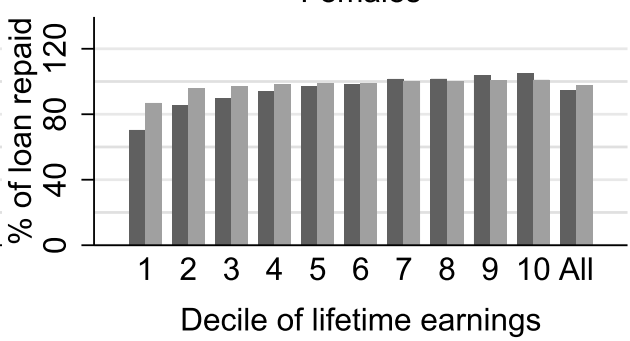

\begin{tabular}{|l|l|}
\hline Write-off & No write-off \\
\hline
\end{tabular}

Fig. 6. Distributional Consequences of Imposing a Surcharge.

the shortfall. Again, to highlight the sensitivity of results to the assumptions about mobility, we show the equivalent figure when no earnings mobility is assumed.

Fig. 7 illustrates that the progressivity of imposing an interest rate above the government cost of borrowing (as with the Stafford loan) depends crucially on earnings mobility. In a country like the US with high graduate earnings mobility it is relatively benign but in countries where this is not true, it means that poorer graduates pay disproportionately more as they pay the high interest for longer. The figure also demonstrates the sensitivity of designing a system to the earnings simulations used, and predicting the distribution of graduate earnings for the next 40 years is never going to be easy.

In these examples we have shown the implications only of changing real interest rates and surcharges. As highlighted earlier, however
(Box 1), these are not the only parameters that can be changed. ${ }^{36} \mathrm{Im}$ portantly, the economic and political implications of charging a surcharge vs higher real interest rates are different and may impact differently on student's borrowing and decisions about university. It also depends on how they interact with other components of the ICL design, the tax and benefit system, the private loan market, and on issues such

\footnotetext{
${ }^{36}$ Other policy parameters include: the number and level of thresholds; repayment rates; write-off period; the maximum loan level and whether a marginal or average repayment rate is applied. Also, the estimates are sensitives to economy wide variables such as earnings growth across the earnings distribution, the government cost of borrowing and inflation (see Britton, van der Erve and Higgins, 2019).
} 


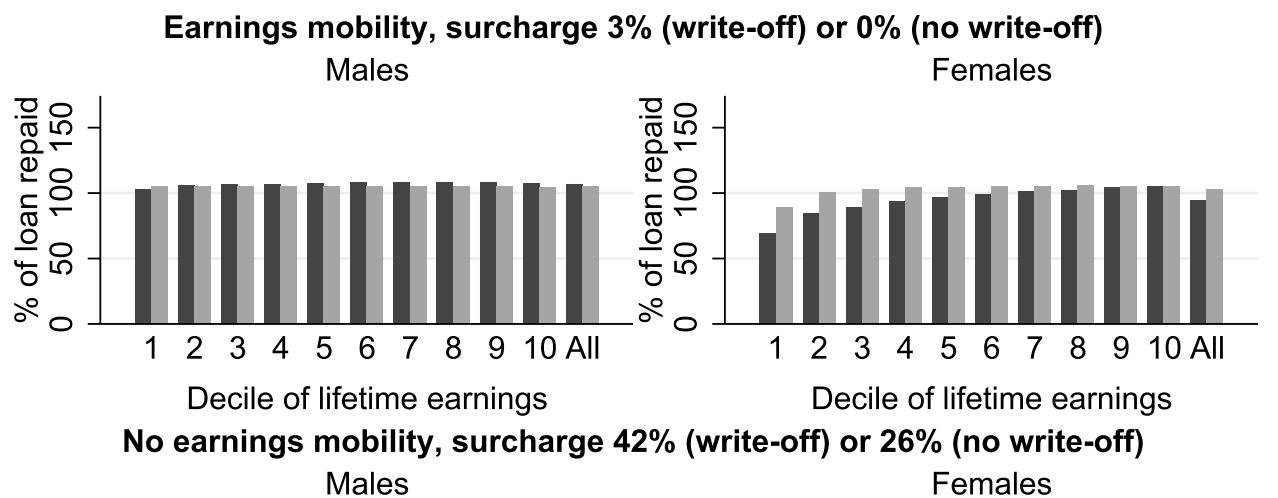

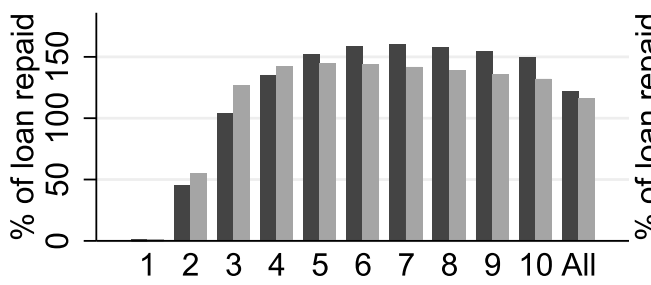

Decile of lifetime earnings

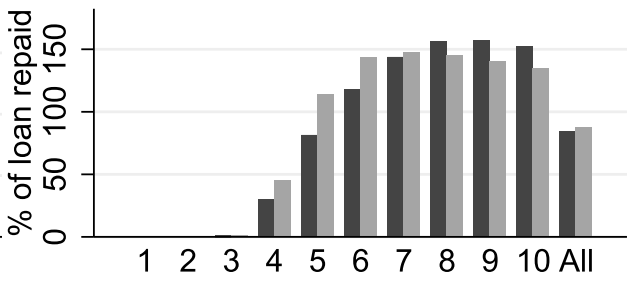

Decile of lifetime earnings

Write-off

No write-off

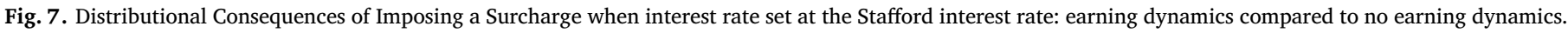

as moral hazard and adverse selection associated with the ICL design.

\section{Comparing ICL and Stafford student loans repayment schedules and burdens for different graduates}

In this section we examine repayment burdens for different types of borrowers under (a) the various ICL schemes discussed in the previous section and (b) Stafford mortgage-type loans (Stafford ML). For this exercise, we would ideally use net income but this is not available in our data. For the vast majority of people, using gross income will underestimate RBs. RBs will also be affected by other factors such as partner's income, which again is not considered in our analysis.

We compare the situation of a female BA graduate who remains in the 35th centile of female BA earnings all her working life with that of a 90th centile male BA graduate. We assume each of our hypothetical students has a debt of $\$ 35,000$ in 2017 prices and a 10 year Stafford ML with a nominal interest rate of $4.45 \%$, the rate applying for those taking out loans in $2017 / 18$. We compare the yearly repayments and repayment burdens for a Stafford Loan with the ICLs delivering a 0\% taxpayer subsidy discussed above and with earnings mobility. ${ }^{37}$

\subsection{Comparison for a low-earning female}

In Fig. 8 we show our estimate of the earnings of this female BA graduate in 2017 \$US and compare this to similar females in the 20th percentile and 50th percentile (median), 75th and 90th percentile of the income distribution throughout her life. Again, we have assumed $1 \%$ annual real earnings growth.

For our example we assume that graduates borrow $\$ 35,000$ over 4 years, the same as was assumed, on average, in the previous section. ${ }^{38}$

\footnotetext{
${ }^{37}$ With the current Stafford MLs the government underwrites defaults, and current estimates suggest that the subsidy is probably close to $20 \%$ of the total value of Stafford MLs (see Looney and Yannelis, 2015).

${ }^{38}$ The average student debt in 2015 was $\$ 30,100$ but this included all debt including private debt. See http://ticas.org/sites/default/files/pub_files/ classof2015.pdf.
}

We consider the following types of loans:

1. Stafford ML with a repayment term of 10 years and a nominal interest rate of $4.45 \%$.

2. An ICL with a $2 \%$ real interest rate above the first threshold and no write-off.

3. An ICL with a $2.9 \%$ real interest rate above the first threshold and write-off after 25 years.

4. An ICL with a loan surcharge of $7 \%, 1 \%$ interest rate above the first threshold and no write-off

5. An ICL with a loan surcharge of $14 \%, 1 \%$ interest rate above the first threshold and write-off after 25 years

6. An ICL with a loan surcharge of $15 \%, 0 \%$ real interest rate and no write-off

7. An ICL with a loan surcharge of $22 \%, 0 \%$ real interest rate and write-off after 25 years

All these ICL schemes involve a taxpayer subsidy of around $0 \%$ when we take into account income dynamics. For the interest rate only schemes we assume that the real interest rate applies only above the first repayment threshold. Remember that because of high default rate the cost of subsidies to Stafford MLs is currently much higher. For all scenarios, as in the previous section, we assume a $2 \%$ rate of inflation and a government real cost of borrowing of $1 \%$.

Fig. 9 shows the annual repayment schedule in 2017 \$US for these schemes for a women earning median earnings throughout her life. We do not consider in detail a women following a lower trajectory, since from Fig. 8 we see that a women in the 20th centile of the earnings distribution throughout her life would pay nothing under this proposed ICL as her lifetime annual earnings remain under $\$ 25,000$. Women staying in the 35 th percentile of the earnings distribution would never pay off their ICL but would face repayment burdens in excess of $60 \%$ when paying their Stafford Loan. An ICL insures them against this excessive RB (see Fig. A1 in the Appendix).

Fig. 9 shows that, with the Stafford loan, around $\$ 4,300$ to $\$ 4,700$ per year (in 2017 \$US) must be repaid for the 10-year period from age 23 to 32 , after which there are no further repayments. With the ICL, the repayment streams and levels are very different. Until age 24 there are 


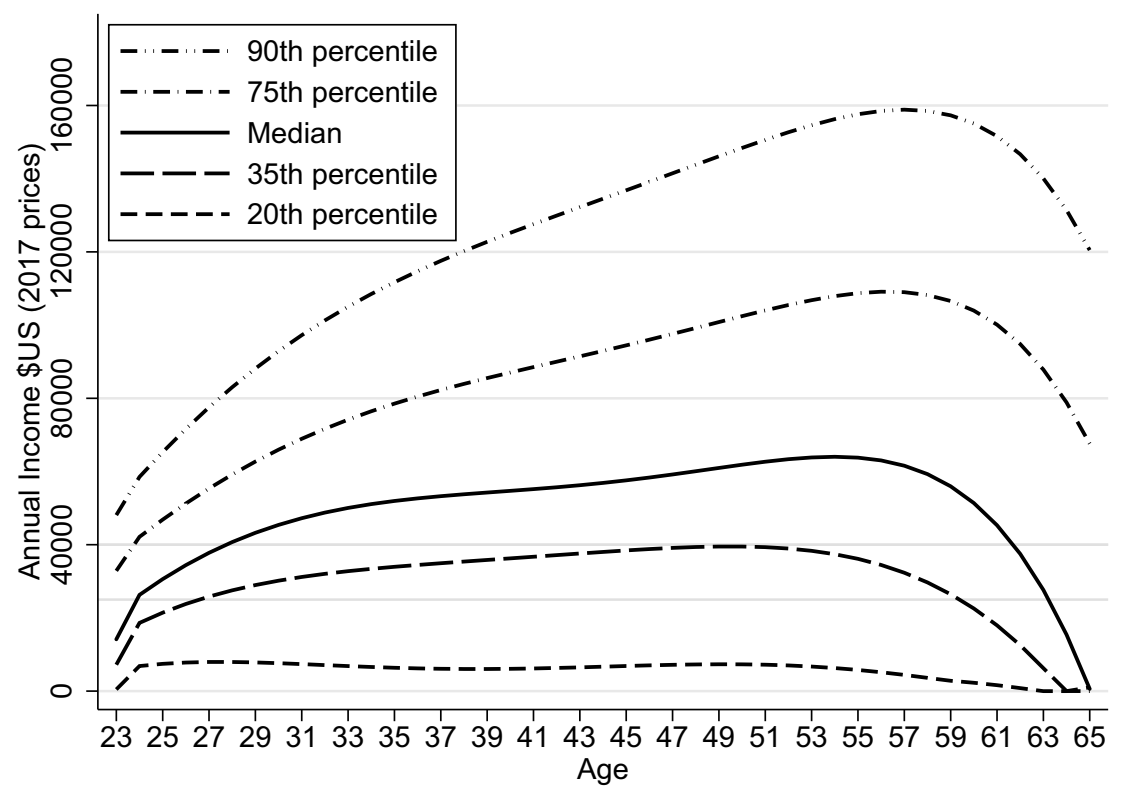

Fig. 8. Female BA Graduate Income throughout Lifetime at different percentiles (in 2017 \$US).

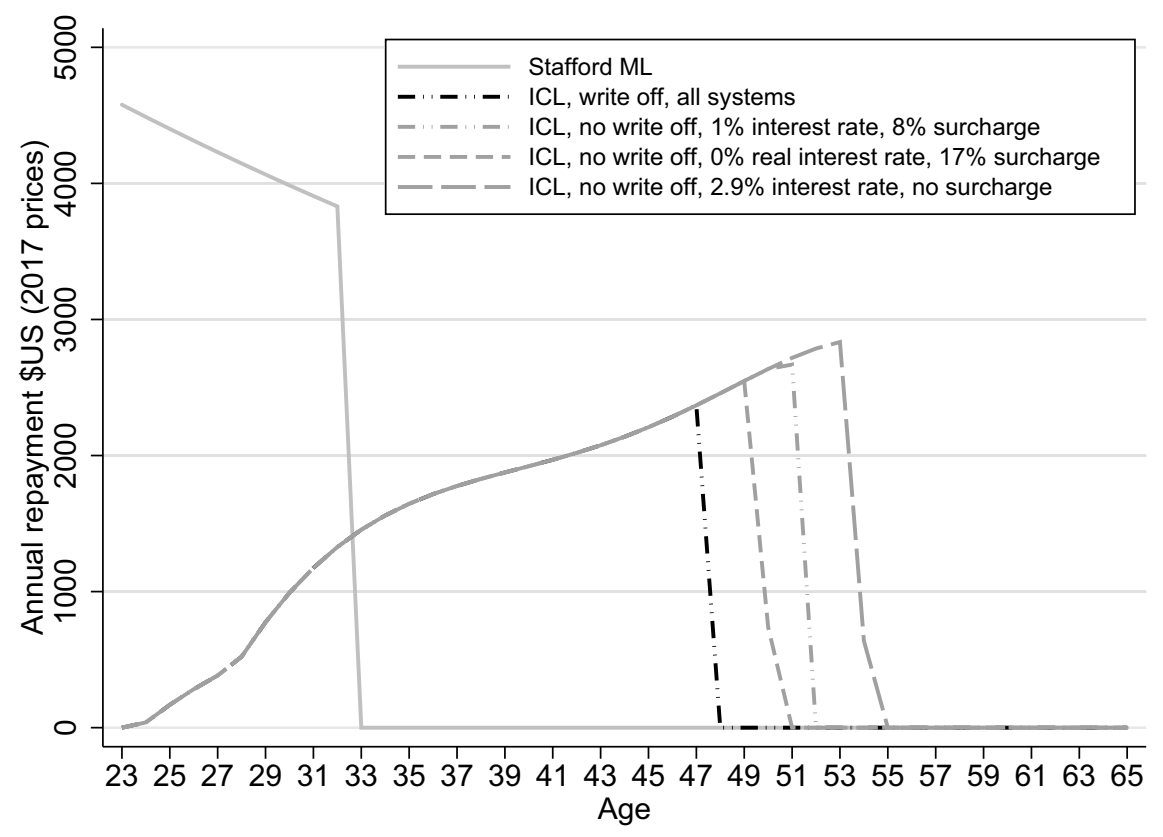

Fig. 9. Female BA Graduate 50th Percentile of Earnings: Repayment Schedule (\$ per year in 2017 prices) for $\$ 35,000$ loan.

no repayments because income is below $\$ 25,000$. Repayments then rise slowly as income rises, and in a scheme with a write-off stop after 25 years with the loan not fully repaid. There is a change in the slope of repayments at the age of 28 when her income goes above the second threshold of $\$ 40,000$. The different schemes have different implications for how long she pays: until the age of 51 with a zero interest rate and surcharge, age 52 with a real interest rate of $1 \%$ and an $8 \%$ surcharge, and 55 with a real interest rate of $2.9 \%$.

Repayment amounts never exceed $\$ 3000$ per year and never come close to approaching Stafford levels, even when this graduate's earnings are relatively healthy. Combining the data from Figs. 8 and 9 allows the calculation of the RBs for each of the loan systems. The results are shown in Fig. 10.

Fig. 10 shows the very different repayment experiences under the Stafford ML and the ICLs for our female graduate. Because the Stafford loan system requires repayment within 10 years, RBs begin at well over $30 \%$ of income, falling to around $8 \%$ by the end of the 10 -year period.
The RB averages just over $12 \%$ of income for the 10 years. In contrast, with the ICL, RBs do not exceed $5 \%$.

The graduate pays around $82 \%$ of her loan with the write-off; $94 \%$ of the loan with the $17 \%$ surcharge, $0 \%$ interest rate and no write-off; $103 \%$ of the loan with a $1 \%$ interest rate, $8 \%$ surcharge and no writeoff; and $116 \%$ with a $2.9 \%$ real interest rate and no surcharge. All these are less than the $111 \%$ she would repay with the Stafford loan (assuming she does not default), with the exception of the $2.9 \%$ real interest rate and no write-off.

However, with women finding themselves in the bottom half of the earnings distribution at young ages, RBs are extremely high with a Stafford ML, and with such high RBs these graduates are very likely to default or experience financial distress. These high RBs have implications for calculating taxpayer subsidies, since the ICL schemes offer insurance, hence debtors are more likely to remain solvent and able to repay some of their debt over their lifetime. 


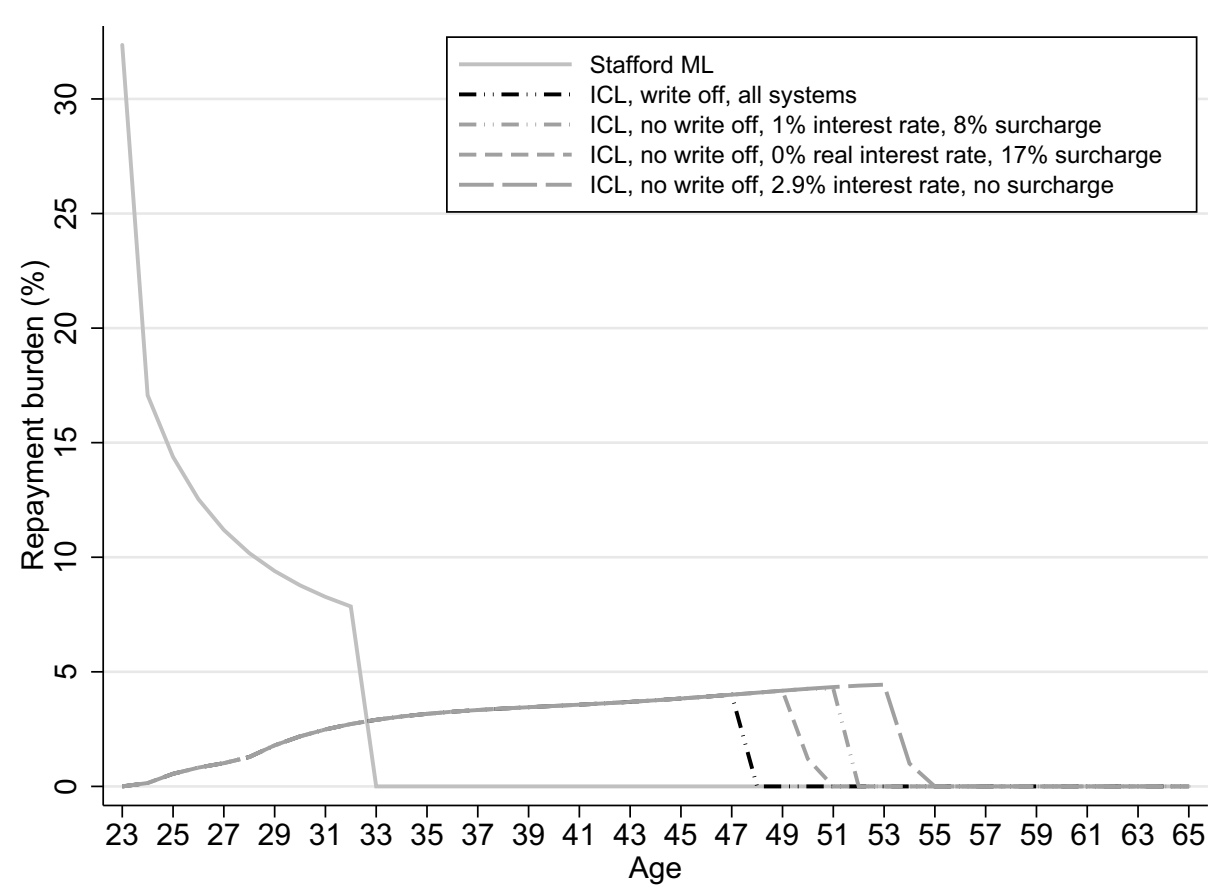

Fig. 10. Female BA Graduate 50th Percentile of Earnings: Average Burden (Repayment/Income) for $\$ 35,000$ loan.

\subsection{Comparison for a high-earning male}

In our final example we consider the implications of the different schemes for a high earning male graduate who has earnings at the 90th percentile of the male graduate earnings distribution throughout his life. Fig. 11 shows how this graduate compares to male graduates in the 20th percentile, 35th percentile, 50th percentile (median) and 75th percentile of the earnings distribution. A male graduate in the 90th percentile is earning $100 \%$ more than median earnings by the age of 40 .

Fig. 12 shows annual repayments under the various loan schemes. As was the case for our female BA graduate (and indeed all graduates), under the Stafford loan, our male graduate must pay around $\$ 4200$ to $\$ 4700$ per year (2017 \$US) over the 10-year period after which there are no further repayments. With the ICL schemes, the repayment streams and levels are quite different, and from two years after graduation are larger than the Stafford repayments so that the loan gets paid 2-3 years faster.

From the figure, the high-earning graduate repays most when there is a write-off, since in a cost-neutral scheme they cover the loss on low earners who benefit from the write-off. He pays $113 \%$ of the loan value in present-value terms with a zero real interest rate and surcharge, as this requires the high earning male graduate to contribute the longest

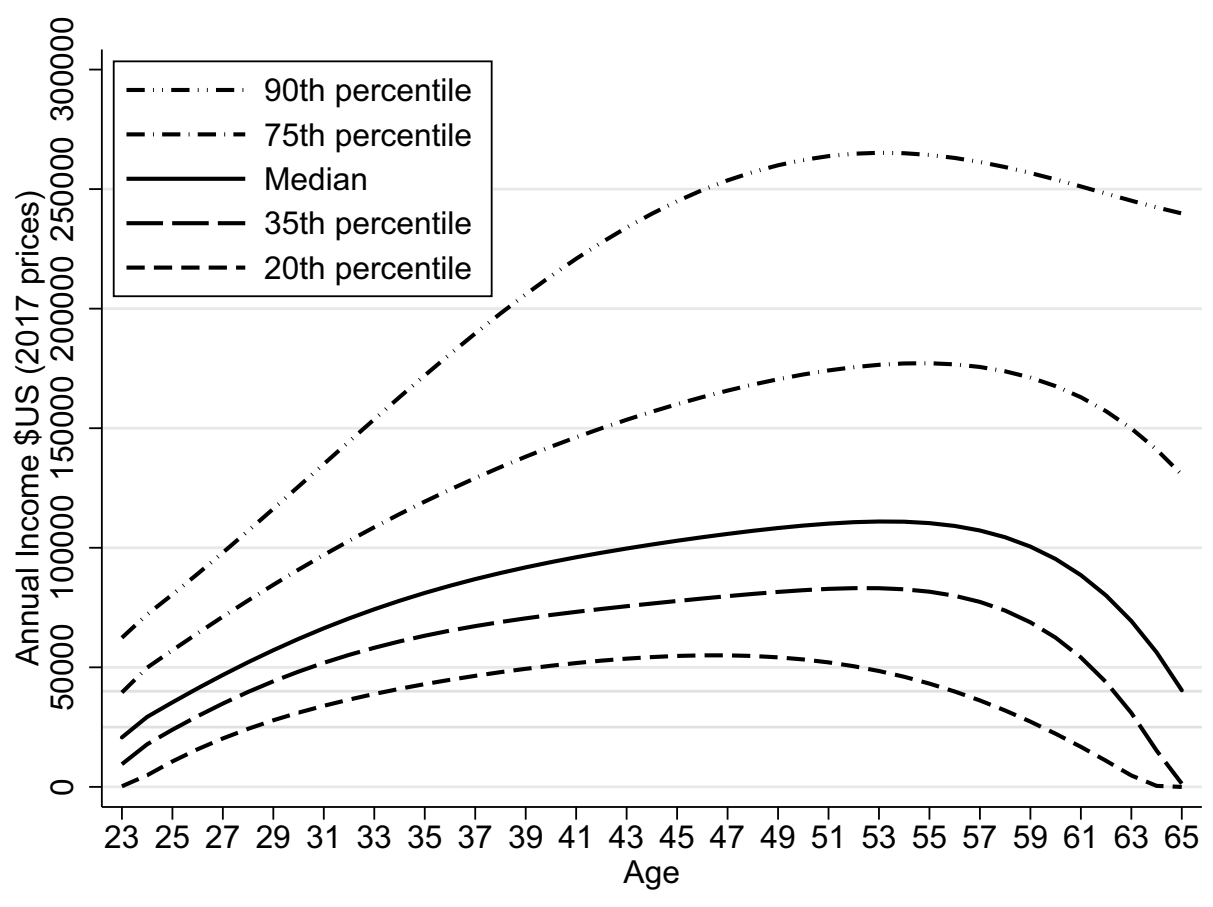

Fig. 11. Male BA Graduate Earnings throughout Lifetime at different percentiles (in 2017 \$US). 


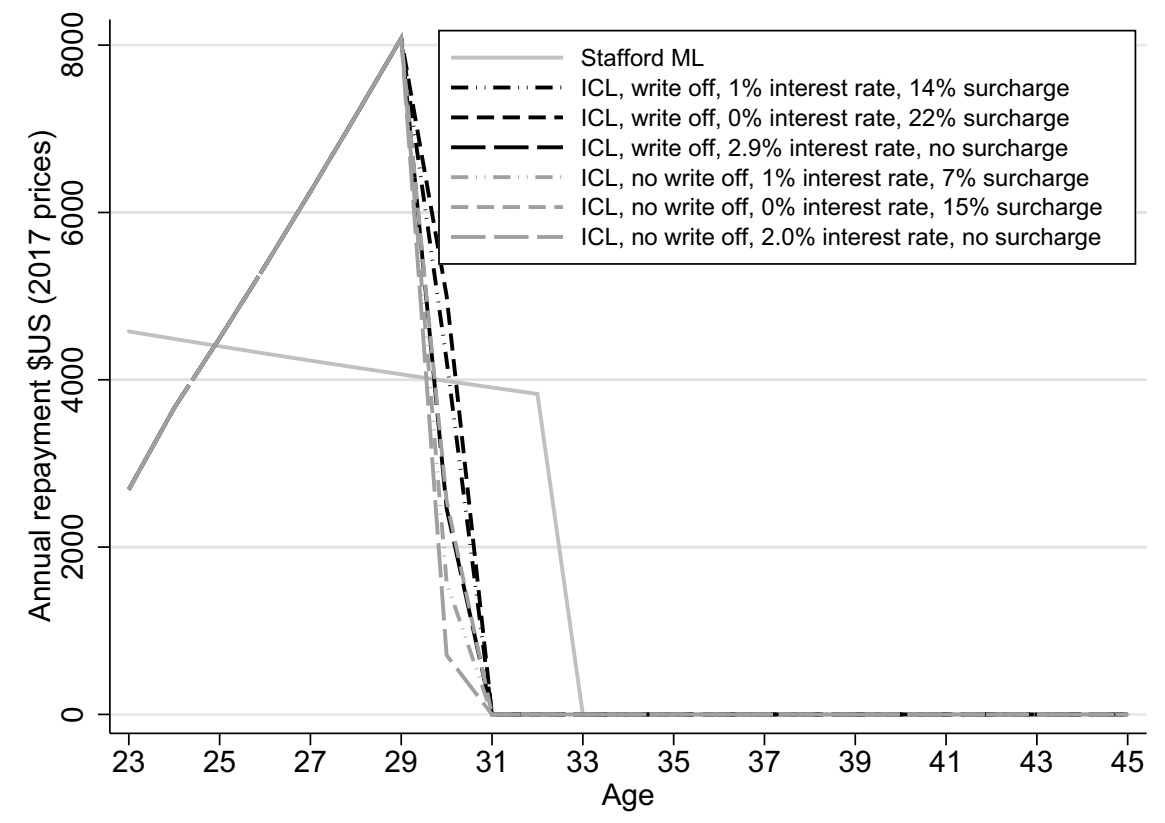

Fig. 12. Male BA Graduate 90th Percentile of Earnings: Repayment Schedule (\$ per year in 2017 prices) for $\$ 35,000$ loan.

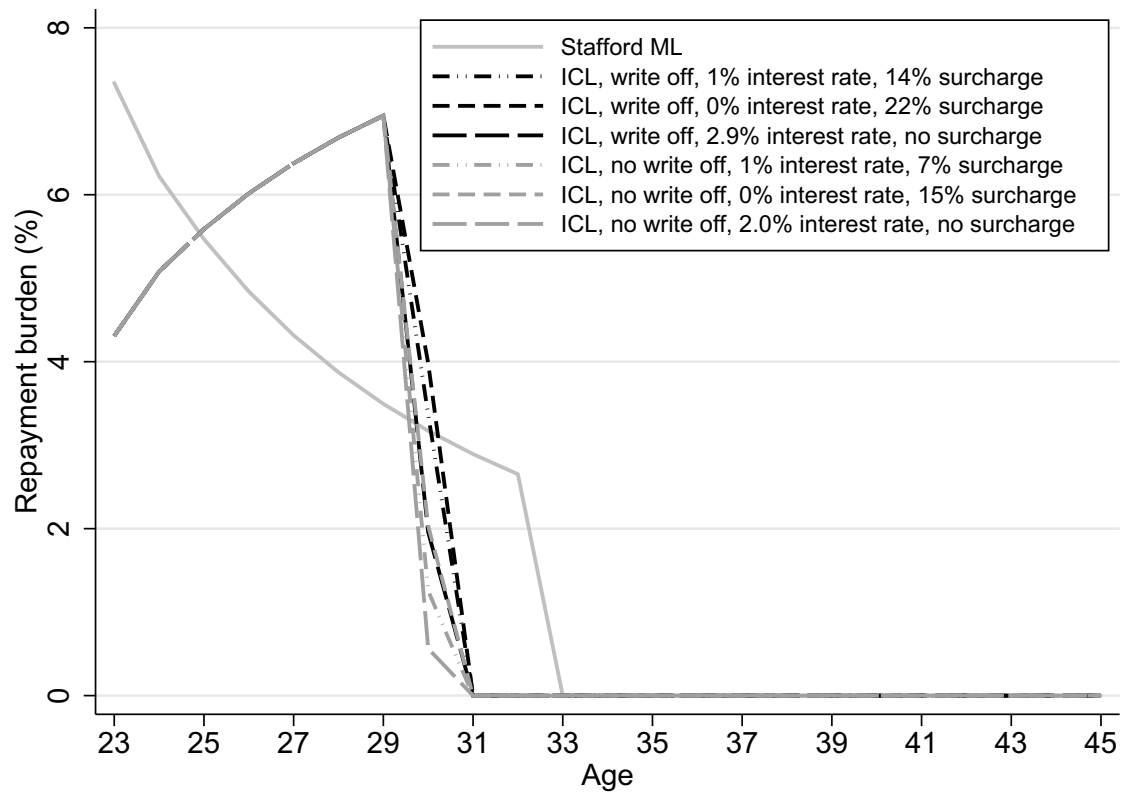

Fig. 13. Male BA Graduate 90th Percentile of Earnings: RB.

and hence to repay the most. With a $1 \%$ interest rate, surcharge and write-off he repays $111 \%$ of the loan value, and with the $2.9 \%$ interest rate and no surcharge repays $106 \%$ of the loan. All but one of the other schemes without a write-off involve a lower cross-subsidy (102\%, 104\% and $107 \%$ ) with the real interest rate and no surcharge providing the lowest contribution.

Again, combining the data from Figs. 11 and 12 allows calculation of the RBs for each of the loan systems. Fig. 13 shows that even this high earning male graduate is protected from having a RB above 7\% under an ICL compared to a Stafford ML (where the RB is just over 7\% in the first year after graduation). This high-earning graduate pays between 4 and $7 \%$ of earnings every year until the loan is paid back. He repays two to three years faster than under a Stafford ML depending on which ICL loan scheme is adopted.

\section{Conclusions and issues for further analysis}

The current design of US student loans creates significant problems, notably the difficulties many students face in repaying. We emphasise that while there is currently a variant of ICL available to some students in the US (known as the income-based repayment loan), in design and effect it is nothing like ICL in Australia and England, and does not have the potential to resolve the major difficulties with student loans in the US.

We began by discussing the considerable risks associated with acquiring a college degree, given substantial uncertainty about individual financial returns to higher education and the lack of collateral for the loan. Loan arrangements such as those in the USA, which generally ignore these uncertainties, have considerable potential to affect borrowers adversely: they create inequity and, if they lead to too little investment in human capital, also inefficiency. 
This paper has drawn on experience in Australia and England to suggest a constructive way to frame the issues. The root problem is that in a conventional loan with fixed monthly repayments, the duration of the loan and monthly repayments are not related to changes in income; a borrower's ability to pay depends crucially on having sufficient income to make repayments affordable.

We have explained the concepts underlying an ICL and illustrated empirically how a well-designed loan can protect low-earning graduates from default or financial distress, while simultaneously keeping taxpayer subsidies low. This contrasts with the current situation in the USA where the default rates on government-backed student loans are significant and rising, in large measure because of the high repayment burdens of Stafford type loans for low income and even moderately lowearning BA graduates, particularly early in their careers. These problems do not arise in countries with ICLs because the design of the loan imposes an upper bound on repayment burdens. ICLs provide consumption smoothing combined with insurance against low earnings that would otherwise lead to default; that insurance increases the efficiency of consumption smoothing and hence of investment in human capital.

Using current data we show that a well-designed ICL system with the characteristics in Box 1 has the potential to address these issues in ways that can be considered to be simple, efficient, equitable and cost effective. We do not claim to have a complete answer, and more detailed work and thinking are required before a comprehensive ICL system can be implemented, including with respect to the following issues.

First, a universal ICL in the USA raises important questions about price setting. Should the government, as ultimate risk taker for unpaid debts, allow private-sector and State-based institutions access to the loan without reference to the level of tuition fees? Or should the government set maximum levels of either prices or loan amounts to guard against high levels of unpaid debt? Palacios (2004) helps inform this discussion with respect to ICL design, an obvious candidate being the maintenance of loan caps such as with the existing system.

Second, what, if anything, is implied for regulation concerning quality assurance, particularly for private-sector institutions with access to the considerable benefits of ICL? Current concerns related to the burgeoning and arguably adverse behaviours of for-profit institutions documented in Dynarski (2016) seem likely to be exacerbated by the general availability of an ICL. This suggests that ICL reform involving the private sector in the US needs to consider the issue of institutional risk sharing. Possible solutions are offered in Palacios (2014).

Third, issues of adverse selection arise if students are provided with choices between existing loan options and a broadly-based ICL. This issue raises the critical matter of universality, with mandatory ICL being the case in Australia.

A fourth issue concerns behavioural responses. One of the arguments against mortgage-type loans is that they create an inefficient incentive towards high-earning jobs at the expense, for example, of jobs like teaching. The analogous issue for income-contingent loans is whether the design inefficiently attenuates student responses to future earnings and/or the cost of their degree. This question raises secondbest issues relating to the tradeoff between higher participation and more equitable access on the one hand and the efficient use of highereducation resources and efficient labour-market choices on the other. We are not aware of any modelling of this issue.

Though work is needed on the details of design, including ensuring feasibility for 2-year college students, ICL approaches in place of a mortgage-type design, have considerable potential to address major concerns about higher education finance in the US. Understanding the propitious experiences of ICLs in Australia and England is an important step in this journey.

\section{Supplementary materials}

Supplementary material associated with this article can be found, in the online version, at doi:10.1016/j.econedurev.2018.07.007.

\section{Appendix}
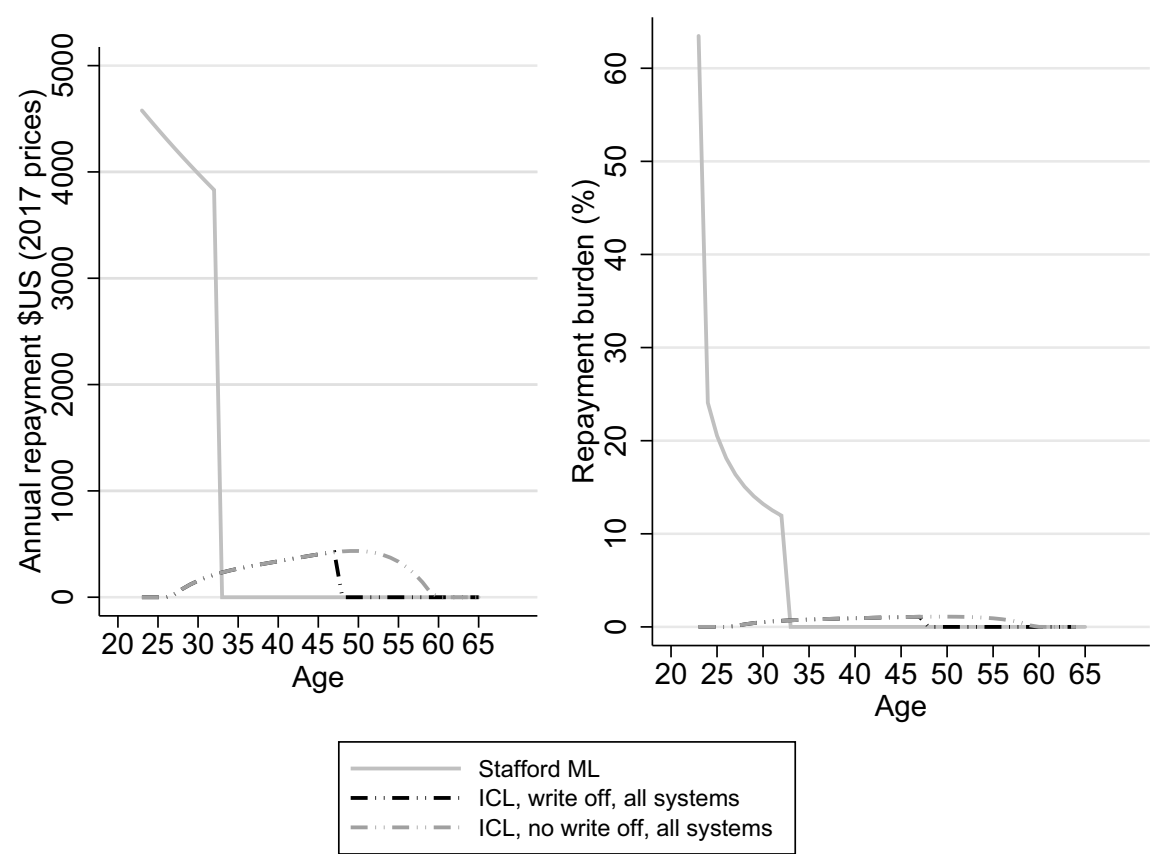

Fig. A1. Female BA Graduate 35th Percentile of Earnings: Repayment Schedule (\$ per year in 2017 prices) and RBs for $\$ 35,000$ loan. 


\section{References}

Barr, N. (1989). Alternative Proposals for Student Loans in the United Kingdom. In M. Woodhall (Ed.). Financial Support for Students: Grants, Loans or Graduate Tax? (pp. 110-121). London: Kogan Page. http://eprints.lse.ac.uk/1804/.

Barr, N. (2012). The Higher Education White Paper: The good, the bad, the unspeakable and the next White Paper. Social Policy and Administration, 46(5), 483-508. https:// onlinelibrary.wiley.com/doi/abs/10.1111/j.1467-9515.2012.00852.x.

Barr, N. (2017). Funding post-compulsory education. In G. Johnes, J. Johnes, T. Agasisti, \& L. López-Torres (Vol. Eds.), Handbook of Contemporary Education Economics: 2017, (pp. 357-380). Cheltenham: Edward Elgar. https://www.e-elgar.com/shop/ handbook-of-contemporary-education-economics.

Belfield, C., Britton, J., \& van de Erve, L. (2017). Higher Education finance reform: Raising the repayment threshold to $£ 25,000$ and freezing the fee cap at $£ 9,250$, IFS Briefing Note BN217, October. https://www.ifs.org.uk/uploads/publications/bns/ BN217.pdf.

Britton, J., van der Erve, L., \& Higgins, T. (2019). Income contingent student loan design: Lessons from around the world. Economics of Education Review, 71, 65-82. https:// doi.org/10.1016/j.econdedurev.2018.06.001.

Center for Economic and Policy Research (2017). CPS ORG Uniform Extracts, Version 2.3, Washington, DC, http://ceprdata.org/cps-uniform-data-extracts/cps-outgoingrotation-group/cps-org-data/.

Chapman, B. (2014). Income Contingent Loans: Background. In B. Chapman, T. Higgins, \& J. E. Stiglitz (Eds.). Income Contingent loans: Theory, practice and prospects (pp. 1119). New York: Palgrave McMillan. https://www.palgrave.com/gb/book/ 9781137413185.

Chapman, B., \& Dearden, L. (2017). Conceptual and Empirical Issues for Alternative Student Loan Designs: The Significance of Loan Repayment Burdens for the US. The Annals of the American Academy of Political and Social Sciences, 671(1), 249-268. http://journals.sagepub.com/doi/abs/10.1177/0002716217703969.

Chapman, B., \& Leigh, A. (2009). Do Very High Tax Rates Induce Bunching? Implications for the Design of Income Contingent Loan Schemes. Economic Record, 85(270), 276-289. https://onlinelibrary.wiley.com/doi/abs/10.1111/j.1475-4932.2009. 00554.x.

Chowdry, H., Dearden, L., Goodman, A., \& Jin, W. (2012). The distributional impact of the 2012-13 higher education funding reforms in England. Fiscal Studies, 23, 211-236. https://doi.org/10.1111/j.1475-5890.2012.00159.x.

Dearden, L. (2019). Evaluating and Designing Student Loan Systems: An overview of empirical approaches. Economics of Education Review, 71, 49-64. https://doi.org/10. 1016/j.econedurev.2018.11.003.
Dynarski, S. (2014). An Economist's Perspective on Student Loans in the United States. BrookingsES Working Paper Series, September. https://www.brookings.edu/wpcontent/uploads/2016/06/economist_perspective_student_loans_dynarski.pdf.

Dynarski, S. (2016). How to - and How Not to - Manage Student Debt. The Milken Institute Review. http://www.milkenreview.org/articles/how-to-and-how-not-to-managestudent-debt $2^{\text {nd }}$ Quarter.

Friedman, M. (1955). The Role of Government in Education. In R. A. Solo (Ed.). Economics and the Public Interest (pp. 123-144). New Brunswick, New Jersey: Rutgers University Press. https://la.utexas.edu/users/hcleaver/330T/ 350kPEEFriedmanRoleOfGovttable.pdf.

Friedman, M., \& Kuznets, S. (1945). Income from Independent Professional Practice. New York: NBER. https://www.nber.org/chapters/c2325.pdf.

Kodde, D. A., \& Ritzen, J. M. M. (1985). The demand for education under capital market imperfections. European Economic Review, 28(3), 347-362. https://www. sciencedirect.com/science/article/pii/S0014292185800131.

Looney, A. and Yannelis, C. (2015). A Crisis in Student Loans? How Changes in the Characteristics of Borrowers and in the Institutions They Attended Contributed to Rising Loan Defaults, Brookings Papers on Economic Activity, Fall 2015, 1-89. 10.1353/ eca.2015.0003, https://www.brookings.edu/bpea-articles/a-crisis-in-student-loanshow-changes-in-the-characteristics-of-borrowers-and-in-the-institutions-theyattended-contributed-to-rising-loan-defaults/.

Looney, A., \& Yannelis, C. (2019). How Useful Are Default Rates? Borrowers with Large Balances and Student Loan Repayment. Economics of Education Review, 71, 135-145. https://doi.org/10.1017/j.econedurev.2018.10.004.

Low, H., Meghir, C., \& Pistaferri, L. (2010). Wage Risk and Employment Risk over the Life Cycle. American Economic Review, 100(4), 1432-1467. https://www.aeaweb.org/ articles?id = 10.1257/aer.100.4.1432.

Nerlove, M. (1975). Some problems in the use of income-contingent loans for the finance of higher education. Journal of Political Economy, 83(1), 157-183. https://www.jstor. org /stable/1833278?seq =1\#page scan tab contents.

Palacios, M. (2004). Investing in Human Capital. Cambridge: Cambridge University Press https://doi.org/10.1017/CBO9780511585982.

Palacios, M. (2014). Overemphasized Costs and Underemphasized Benefits of Income Contingent Financing. In B. Chapman, T. Higgins, \& J. E. Stiglitz (Eds.). Income Contingent loans: Theory, practice and prospects (pp. 207-215). New York: Palgrave McMillan. https://www.palgrave.com/gb/book/9781137413185.

Stiglitz, J. E. (2014). Remarks on income contingent loans mitigating risk. In B. Chapman, T. Higgins, \& J. E. Stiglitz (Eds.). Income Contingent loans: Theory, practice and prospects (pp. 29-37). New York: Palgrave McMillan. https://www.palgrave.com/gb/ book/9781137413185. 